\title{
The Mayan gods: an explanation from the structures of thought
}

\begin{abstract}
This article explains the existence of the Classic and Post-classic Mayan gods through the cognitive structure through which the Maya perceived and interpreted their world. This structure is none other than that built by every member of the human species during its early ontogenesis to interact with the outer world: the structure of action. When this scheme is applied to the world's interpretation, the phenomena in it and the world as a whole appears as manifestations of a force that lies behind or within all of them and which are perceived similarly to human subjects. This scheme, which finds application in the Mayan worldview, helps to understand the personality and character of figures such as the solar god, the rain god, the sky god, the jaguar god and the gods of Venus. The application of the cognitive schema as driving logic also helps to understand the Maya established relationships between some animals, such as the jaguar and the rattlesnake and the highest deities. The study is part of the pioneering work that seeks to integrate the study of cognition development throughout history to the understanding of the historical and cultural manifestations of our country, especially of the Pre-Hispanic cultures.
\end{abstract}

Keywords: Mayan gods, logic of thought, structure of action, subject/object, qualities perception
Volume 3 Issue I - 2018

\author{
Laura Ibarra García \\ Universidad de Guadalajara, Mexico
}

Correspondence: Laura Ibarra García, Centro Universitario de Ciencias Sociales, Mexico, Tel 523336404456, Email95nubi@megared.net.mx

Received: August 30, 2017 | Published: February 09, 2018

\section{The mayan gods: an explanation through their thinking patterns}

The ancient Maya, like many other early cultures, developed a body of beliefs and myths on which they based their explanations for the origin and order of the cosmos. Everything that exists and happens was understood as the action of invisible and impalpable divine energies, beings or deities, who found representation through art and whose exploits were told in the sacred books. Some gods dealt with the natural phenomena related to the celestial space, others with the terrestrial environment and some others with the underworld, although most of them went beyond the scope of their functions and acted in areas other than their own. ${ }^{1}$

In addition to this categorization of the Maya deities (in accordance to the cosmos level in which they act), there are other classifications or groupings based on other criteria. For example, Nikolai Grube groups the codices deities' according to the beneficial or harmful influence they exert on the world of men, in positive and negative gods. ${ }^{2}$ Karl Taube, ${ }^{3}$ following Schellhas's classification, studies the gods according to the religious tradition to which they belong, thus, in his documentation, appear first the gods of Mayan origin and then the "foreign gods" from the Postclassic. ${ }^{3}$ Baudez divides these supernatural beings into those related to an aspect of the wet, alive, fertile soil and those linked to the dry, dead and sterile aspect. ${ }^{4}$ According to the images and the iconography, Baudez makes a special distinction: on one hand, the 'flat noses', or beings whose feline and solar features are related to the dry underworld, the realm of the nocturnal sun, the world of the dead and so on; and, on the other, the "prominent snouts", whose features resemble reptiles, associated with life and the fertile soil. ${ }^{4}$

Some researchers study the Mayan gods according to some theoretical approach, chronological space, particular aspects of the deities or according to the source who reports them. For example, Stone and Zender analyze them by their hieroglyphics and iconography; ${ }^{5}$ Juan Luis Bonor studies the gods worshipped in caves, ${ }^{6}$ María Eugenia Gutiérrez investigates the gods of time, ${ }^{7}$ etc. The knowledge we have about these supernatural beings comes mainly from their representations sculpted in stone, stucco, wood, bone, shell or jadeite and other materials. Their images were captured in clayshaped censers, such as those in Palenque, in stelaes, as in Copán, or in vault lids. There are vast numbers of sculptural contexts usually scenes in bas-relief in which the divinities can be identified.

In recent times, the images of the Mayan gods found in ceramic vessels are added to these sources, thanks to private collections being opened to researchers. During the Classical period (250 AD - $900 \mathrm{AD}$ ), painted pottery displayed mythological and ceremonial scenes, for it was destined to be part of funerary offerings, to serve as a ceremonial vessel or in the dedication of certain monuments. ${ }^{8}$ Pre-Hispanic pictorial manuscripts have been a key to acquaint ourselves with the Mayan gods; of which only three are preserved: the Dresden, Madrid and Paris codices. All of them of divinatory nature and contain mostly calendar records that include ceremonies such as the New Year and topics such as agriculture, hunting, the rainy season and the deities associated with each one of them, which has made it possible to differentiate the deities of the Mayan pantheon by traits and characteristics. ${ }^{2}$ Other sources are the colonial, indigenous and Spanish texts, some of them with deep roots in the pre-Hispanic period, which have contributed to confirm the personality and functions of the sacred beings. ${ }^{9}$

The Dresden Codex seems to come from Yucatan, specifically, from Chichén Itzá, in Thompson's view. ${ }^{10}$ After a careful analysis of the dates, the style of some censers, the years' markers, the gods represented, as well as the use of some glyphs, the British archaeologist concluded that this codex is probably a copy of an older 
one and that it was made between 1200 and 1250 in Itzá. The origin of the Paris Codex is unknown, but epigraphic and iconographic studies performed by Thompson and Love agree that it might come from some place within the Yucatan peninsula, such as Mayapán, or from the East Coast area and that it should be dated around the fifteenth century. On the other hand, the Madrid Codex contains elements that relate it to the Coast of Campeche and for internal calendar evidences it is supposed to be written between the XIV and XV centuries. ${ }^{11}$

Also, in recent years, advances in epigraphy have been added to this set of sources. The decoding of texts written by the Maya themselves using hieroglyphic writing has helped to understand the personality and functions of the deities. As Simon Martin asserts, their writing was an attempt to give the transcendent a tangible form and to make visible what they considered hidden. ${ }^{12}$ At the beginning of the 20th century, Paul Schellhas identified the first images of the divine figures in the Post classic codices (900 AD - 1500 AD), which, given the impossibility of clearly establishing their names, were given a capital letter to name each one, from A to P. ${ }^{13}$ Although the dramatic advance in decoding Mayan hieroglyphic writing over the last two decades has made it possible to know the names of almost all of the gods, Schellhas's nomenclature, although modified, is still used to identify the images of the major gods (Figure 1).

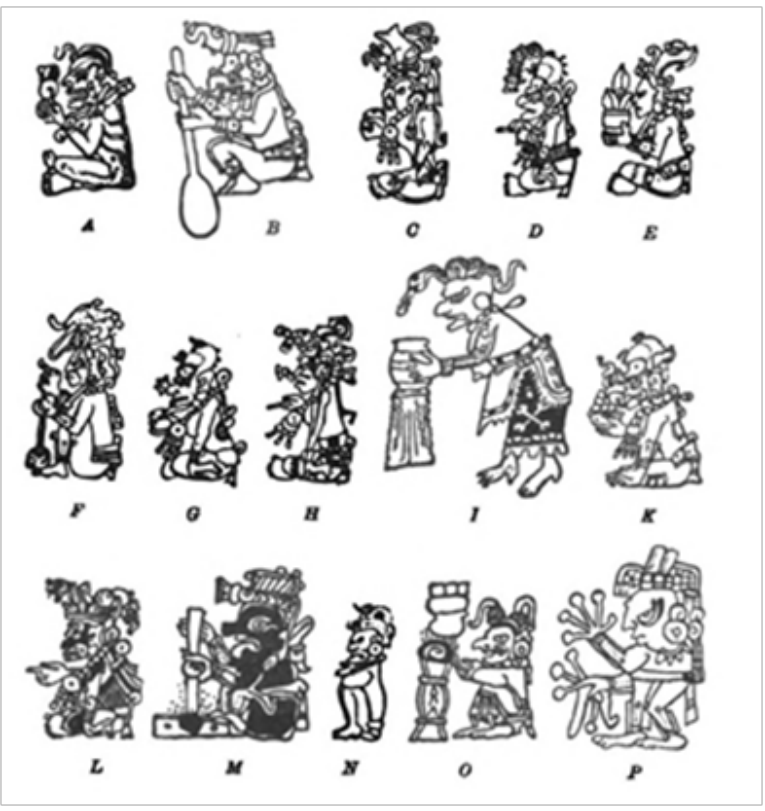

Figure I Schellhas list of gods.

The Maya used the term $k$ 'uh to refer to their gods. Diego López de Cogolludo, in his "Historia de Yucatán" (Yucatan's History), published in 1688, recorded that the natives of that land designated their god with the term $k u$ and specifies: "in their language $k u$ means the same as god in our Castilian". ${ }^{14}$ This term never accompanies the personal names of high dignitaries or rulers, who were called $k^{\prime} u h u l$ ajaw, "holy" or "divine lord", but never k'uh ajaw, reason why researchers agree that the term $k$ 'Uh, "god", is a specific hieroglyphic that was applied exclusively to the deitie.

Each of the Mayan supernatural beings has various epiphanies or titles and is represented in numerous ways. Some gods have several names, such as God A, called Yum Cimih, Cisin, or Uac Mitun Ahau ${ }^{3}$ Or the Goddess O, who, depending on her title, was called Sak U'Ixik, "Lady White Moon"; Chak Chel, "Big Rainbow"; Ix Chebel Yax,
"Lady of the First Brush" and Ix Chel, "Glowing Lady or Lady of the Rainbow". ${ }^{15}$ Some Mayan gods are sometimes one and many at the same time. They are usually pluralized in four, so, for example, there is a rain god, Chahk, but there are also four chahks gods, responsible for the four cardinal points. ${ }^{3}$ This is also observed in the representations of the old god or God N, who is also pluralized in four to assume the function of supporting the sky or some monuments. ${ }^{12}$

Mayan deities can cause favorable or harmful phenomena for mankind. Under this perspective, Grube distributes the gods in the codices, depending on their attributes, into two groups: one positive and one negative. The god of water, that of corn and the elder god of creation, Itzamnaaj, are part of the group of positive gods. Among the negatives is the god of death, easily recognizable by his skeletal body and the god K'inich Ajaw, "lord of the sun", because he could burn the crops with his hot rays. ${ }^{2}$ However, the same god can also influence positively at certain and at others in a detrimental way, ${ }^{15}$ which is manifested in plastic works by adding symbols of death to the usual deity aspect. ${ }^{16}$

Most of the gods are male, but there was a young moon goddess, Goddess I, whose name was Ixik Uh, "Lady Moon." Perez Suarez believes that this goddess was associated with the crescent moon, while Goddess O, represented as an old woman, was associated with the waning moon. ${ }^{15}$ The Mayan gods also show a strong tendency to identify themselves with each other; the figures that represent them sometimes show attributes of several deities. For example, $K^{\prime}$ 'awiil's serpent foot is a personification of Chahk's ax-thunderbolt. ${ }^{17} \mathrm{~A}$ detail on the K3367 vessel shows the corn god in turn with the serpent leg, attribute of the god $\mathrm{K}^{\prime}$ awiil ${ }^{17}$ (Figure 2). Taube considers that this hybrid character, this mixture of traits of different gods, is a common feature of the Mayan deities. ${ }^{17} \mathrm{~A}$ good example of the gods fusion is provided by the detailed study of Simon Martin, which analyzes the substantial number of combinations or mixtures of the old god, god I and:
a. the gods that support the sky,
b. the sky and earth monster,
c. the Bird Principal Deity,
d. the creator god Itzamnaaj,
e. the god of the underworld and
f. Other deities. ${ }^{12}$

Something similar happens with the names of the deities, which frequently integrate elements of the names of other gods. Valencia points out, for example, that in some contexts, not only during the Classic but also in the colonial period, the name Itzamnaaj K'awiil, which "fuses" the deities Itzamnaaj and $K^{\prime}$ 'awiil, turns up. ${ }^{18}$ Although at first these amalgamations create confusion, such links show the coincidence of meanings. The frequent mixing of Chahk and K'awiil is perhaps the consequence of both sharing the role of lightning gods. ${ }^{17,1}$

And just like the personality and character of the gods are blurred, their actions exceed the limits of their scope as well, so it is not easy to define which part of the Maya cosmos they operate in. ${ }^{18}$ Numerous studies on the nature of supernatural beings have parted from their

\footnotetext{
${ }^{1}$ García Barrios points out the difficulty of recognizing the gods when a deity takes aspects of different gods, as for example, with god $\mathrm{L}$, god $\mathrm{N}$ and Itzamnaaj. ${ }^{1}$
} 
origin in some of the forces of nature, such as storms or lightning, or in their association with celestial bodies such as the sun, moon or Venus, or with the corn or death and, in consequence, they undertake a classification that places the deities at some level of the Mayan cosmos. ${ }^{11,19,20}$ However, Mayan gods act in spheres or contexts of action that go beyond these frameworks. Thus, it is now accepted that this kind of taxonomy clarifies essential aspects of the divinities, but leaves others out. Houston and Stuart have criticized the vision that implies deities with clear profiles and fields of action well delimited, since they consider that it is an excessive use of the western concept of god applied to cultures whose understanding of the divine is far from that which prevailed in Europe in the last centuries. ${ }^{21}$

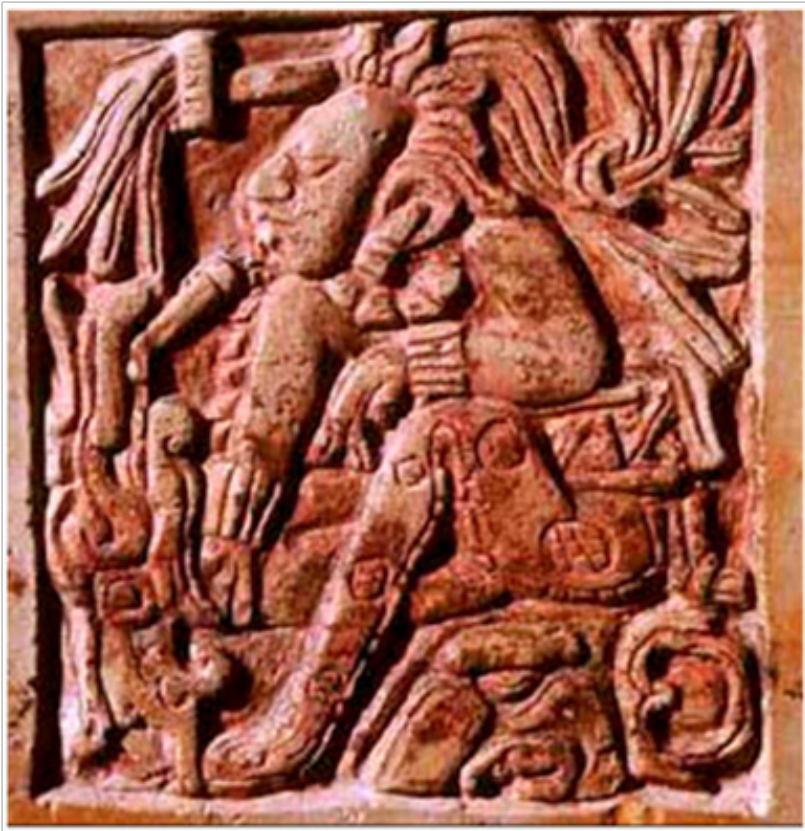

Figure $\mathbf{2}$ The corn/maize god with a snake leg. Detail from vessel K3367.

In the iconographic sources, especially from the Classical period, the Mayan gods appear in very varied situations of interaction. ${ }^{18}$ For example, the god $K^{\prime}$ awill frequently changes location to intervene in various mythological events: He participates in the formation of storms and in the fall of lightning, promotes the growth of corn seeds, intervenes with the god $\mathrm{L}$ in the realization of several rituals, represents cocoa, but also wealth and its powers allow the appearance of jaguar-like beings, which give body to animated entities that form part of the body of the sorcerers to attack their enemies. ${ }^{18}$

The Mayan religion was not in an advanced systematization stage, nor did it form a single and identical body of beliefs. ${ }^{2}$ What is generically known as "Mayan culture" is made up of many communities that had different religious conceptions. This entailed very different plastic representations for each of the gods. And, if one adds that each region had its own artistic style, it will be obvious that the study of the Mayan gods is not easy. In addition, in the Postclassic period the Maya pantheon still consisted of a particularly heterogeneous set, with only a few figures recognized throughout the whole area and many deities that were only known in limited

${ }^{2}$ We understand as systematization an organized and hierarchical pantheon in which the gods have a set identity (appearance, status and power) and defined attributions, relations and functions. While the existence of certain deities over time contributes to being systematized by the sacerdotal elite, this does not ensure a systematized order of belief. geographical spaces. ${ }^{21}$ Because of this, it is difficult for specialists to carry out a study that includes most of the deities of the entire Mayan region, since, frankly, many are little known.

We should also keep in mind that the Mayan religion had important changes during its development it is a phenomenon immersed in a cultural development of thousands of years especially in the cultural transition from the Classic to the Post classic, marked by the arrival of Nahuatl groups To the Maya area around the year 1000 AD. ${ }^{3}$ Other deities joined the existing pantheon, introduced by these peoples into both the Yucatan Peninsula and the highlands of Guatemala, such as Quetzalcoatl, the "feathered serpent", which merged with the figure of the Mayan celestial monster. In this paper we pay attention to the deities whose existence can be followed for centuries in the Mayan religion, such as the solar god, that of the rain, or the supreme creative deity, which are also present in multiple stelaes and monuments of the region in which the Mayan culture developed, that is, Mexico's southeast, Guatemala, Belize and the western area of Honduras and El Salvador. ${ }^{22}$

The present study does not pretend to characterize the Mayan deities, there are many publications on this subject its goal is rather to show how the gods in Mayan culture are the result of a functioning mental schematism, which is formed during the initial stages of every man's ontogenesis. It tries to answer the question, how was it possible for the Maya to have organized their external world through subjective agencies, or gods and not personified cosmic forces as well? The path reconstructed here to understand how the gods were introduced in Maya culture does not accurately trace the deities' transformations that can be seen in stelae or monuments along a millenary development, but it's rather interested in clarifying the reasons why the gods existed for the Maya, from a perspective that deals mainly with the categorical ways through which mankind understands the world. To do this, it is necessary to place oneself in the Maya's place and, from there, understand how they perceived and interpreted their world, which means to have in mind the ways of thinking on which they based their worldview and its structural characteristics. These forms of thought formed the basis not only of their perception of what exists and occurs, but also of almost all their beliefs, myths and rituals. Even the most recalcitrant adversaries of an approach that contemplates cognitive structures as sustenance of Maya thought must admit that they exist and that they determine the way reality turns into a world with causal relationships and an order in temporal and spatial sequences.

The methodological strategy that we follow is based on the assumption that every man, since birth, begins a process in which at the same time that he develops mental structures he coordinates his motor skills so that he can interact with the outside world effectively. The thinking patterns formed here, later find application in the worldview. The documentation that we present hereunder must show that the logic formed during the ontogenesis is indeed that which is applied in the conceptualization of the Maya world. In this, it is necessary to note that there is a difference between the structure and its anthropomorphic incarnation. This strategy poses a significant gain, since it resorts to the ultimate reasons that explain why the ways

${ }^{3}$ The Central Highlands groups' belief system at this time was not the only external religious influence in the Mayan religion. Grube and Martin have demonstrated the presence of foreign groups in the Mayan area since 360 AD. To give an example, the remains of Teotihuacan style in the city of Tikal, are the witness of a military incursion that came to replace the ruling dynasty of that city. ${ }^{23}$ 
of thinking the ways they are, the Mayan gods among them are. This goes beyond the merely descriptive level, which only reports how things are $^{4}$. On the advantage of logical-structural reconstruction, Günter Dux affirms categorically that: "Now we can say why we understand strange cultures, what it is that allows us to understand them and how much we can understand them". ${ }^{24}$

Specifically, the method we follow here is the very same as that of the research initiated by Piaget's genetic epistemology, which parts from the empirical forms of thought (in any of its many forms, such as the children's thinking, the adult's, the early cultures, the scientific, etc.) and reconstructs the structures on which it rests, to then explain them. Certainly, these structures do not confirm an arbitrary logic. They also must be explained from the conditions they arise from and must be able to explain the formation and development of the thought forms we find in the ontogenesis and philogenesis. These structures are not archetypes deposited in the human spirit in some strange way. These archetypes do not exist, because, who would place them? Nor are these the structures like those proposed by structural anthropology. Because, structures of which can only be said that they follow "human inclinations", or "the unconscious activity of thought", remain as invisible as the archetypes. ${ }^{24}$

\section{The logic of mayan thinking}

If we want to understand why the Maya perceived the universe so populated by sacred forces that determine nature's phenomena and are somehow similar to humans to greater or lesser degree, it is necessary to consider the cognitive paradigm by which they built their world. This paradigm is formed by the structure developed by every member of the anthropological species in its early ontogenesis to access the world and forms the underlying basis of every idea and every human belief. ${ }^{28}$ Given that the human organism is incapable of maintaining itself alive at birth, it must develop mental and practical capacities through its interaction with a more competent adult to ensure its survival in the future. During this process, the construction of schemes and categories that allow him to integrate his own actions to the world play a fundamental role.

There are several attempts to explain the ways of thinking of early cultures, however, most of them have an essential lack, because it is unclear where the logic of thought arises from and how and why it is articulated in a certain way in the worldviews. For this reason, it is vitally important to resort first to the ontogenesis and to observe there the formation of mental schemes to interpret reality. Every member of the human species must learn in the initial stages of his life to coordinate his motor skills and to make his intentions the goal of his action. By coordinating their motor skills, reality is simultaneously ordered. The process through which actions increase his competence has decisive consequences on the formation of thought and its categories: the structure built by exercising action remains linked to it in the cognitive system as well. For this reason, the internal organizations of the structures that allow us to perceive and understand the world assume the scheme of action. ${ }^{29}$

The scheme of action that is built in the early phase of ontogenesis to ensure access to reality, as well as the categories of object and event (or fact) that are constructed with this scheme, were decisive in the construction of the understanding of the Mayan world. How

${ }^{4}$ The works of CR Hallpike; ${ }^{25}$ U Wenzel; $;{ }^{26}$ Dux; ${ }^{24}$ Ibarra $^{27}$ can be mentioned among the many investigations on the cognitive structure of thought in early cultures. could a thought, which has no other logic to understand the world than the scheme of action, apply another paradigm to interpret the objects and events it encounters? If we bear in mind that the Mayans' idea of natural phenomena, such as rain, the movement of the sun or the growth of maize, is based on the scheme of action, then it is possible to explain the specific process in which their deities arose. The perception and interpretation of the world's phenomena is a manifestation of sacred forces resembling human beings results from way of thinking which assumes the structure of action. When the mind reflects on the world or its phenomena, these are understood as actions. Therefore, the phenomenon assumes a dynamic in which its beginning or origin lies in the subject. ${ }^{24}$

When the mind reflects on a phenomenon or the world as a whole, a discourse that takes on subjectivist forms is articulated, that is, it refers to a subject (or its subjectivity) that undertakes an action. In the structure of human action, it always has an origin from which it emerges: subjectivity. No matter what external stimulus may drive the action, nor what type it is, subjectivity is what always sets in motion and organizes the action. When this scheme is applied to make the world comprehensible, the origin of the phenomenon, like in the structure of action, lies in an agent who has the vigor to set it in motion. In a causality that assumes the structure of action, the cause of the event is not reduced to subjectivity, because the origin of the action, besides being the intangible subjectivity, is the real object, that is, the corporeal materiality of the subject. Therefore, when the structure of action is applied to understand the world, origin not only appears as a subject, but also as a substance that has the creative force of subjectivity. As soon as the agent resulting from that process is given a name, it becomes one of the creative deities.

Although this explanatory paradigm found application in the belief systems of the early cultures, its application was subject to specific conditions that contributed to the equally specific character of each religion and particularly of each deity, myth or ritual. To explain the cognitive processes behind the creation of a pantheon of deities, such as the Maya, it is necessary to keep in mind the formation process of cognitive schemas, understand their structural moments and then reconstruct the particular way in which the cognitive structure is applied to the level of world conception and turns each religious tradition into a unique and sui generis phenomenon. Let us now see how the logic of action as an interpretive scheme found application in some of the major Mayan gods.

\section{K'inich Ajaw, the solar god, god $\mathbf{G}^{\mathbf{5}}$}

K'inich Ajaw, "Lord of the Great Sun", was one of the most important Mayan gods, also known as K'in, "Sun" or "Day"; or Ajaw $K^{\prime}$ 'in, "Lord of the sun", among others. ${ }^{5}$ In the representations, $K^{\prime}$ 'inich Ajaw appears as an elder man with an aquiline nose and a triangular tooth and his pupils, in the upper inner corner of the eye, make him seem cross-eyed ${ }^{3}$ (Figure 3 ). Sometimes he looks very similar the supreme deity, Itzamnaaj, but it is distinguished by the kin glyph, which reproduces a four-petalled flower ${ }^{5}$ and a band that hangs at the corner of the mouth a serpentine symbol, sometimes painted red. His prominent nose and wrinkled cheeks project maturity, but not decrepitude, which characterizes other elder gods. ${ }^{5}$ In the Pre-classic

${ }^{5}$ The Mayan orthography regarding the names of the gods has not been generalized among the researchers. Although there are attempts to normalize their writing, recognized scholars differ as to the manner in which the nominatives of the deities should be written. Here I follow the spelling proposed by Stone and Zender in his publication Maya Reading Art. ${ }^{5}$ 
and Post-classic, he is shown with a beard, which represents sunrays. In Yucatec, solar rays are eluded with the expression $u$ mex kin, "beard of the sun". ${ }^{1}$ K'inich Ajaw was a feared god, for he was responsible for the drought, for without the rains the sun would burn the crops. From his name is derived $k^{\prime}$ ihnich, "solar, angry and furious".

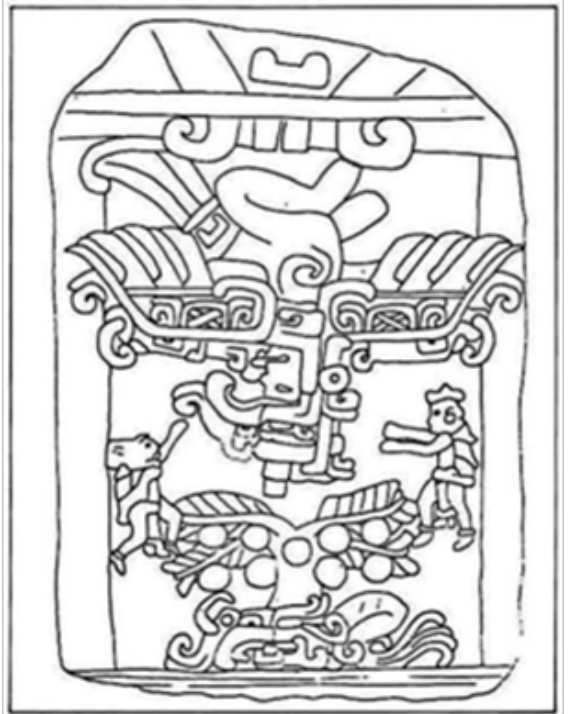

Figure 3 Izapa's Stela 2.The solar deity enters head down into the underworld.

Every day, the solar god finishes a cycle: at dawn, it emerges from the underworld and travels across the sky, filling the world with light, heat and life and, at dusk, he transmutes into a jaguar and descends again to the underworld. Hence the sun was identified with this animal. This journey gave K'inich Ajaw ambivalent qualities, for during his diurnal journey he was seen as a force of order and kindness and, in his aspect of jaguar god of the underworld he was related to night, war and death. The kin glyph sometimes appears in the face of the jaguar god of the underworld. ${ }^{5}$ The red color refers to the scorching heat of the sun and masculine vitality. In the censers used in rituals, the kin glyph often appears on the bowl. ${ }^{5}$

In classical works, the sun god is often depicted as about to be devoured between the jaws of the terrestrial monster or snake, or also as coming out of the jaws after having toured the dark regions of the underworld. In Toniná, there is a large dragon figurehead, located at ground level, which hold a sphere inside its jaws, clearly representing the sun. ${ }^{30}$ Izapa's Stela 2 shows the moment in which the solar deity enters, head down, the underworld. Before entering, the offerors provide the deity with food to ensure the success of his journey ${ }^{31}$ (Figure 4).

In Palenque, the god G III is a solar deity. ${ }^{32,6}$ It is probably the Jaguar Sun of the Underworld, ruler of the Temple of the Sun. ${ }^{33}$ In the Temple of the Sun's interior chamber's triptych, you can see a prominent shield with the countenance of the sun, leaning on the backs of two supernatural infernal beings, which are in turn seated on a band of signs that allude to the underworld. In other words, the image represents the sun in its journey to the interior of the earth, right in the moments when it sinks into the telluric abyss, ${ }^{8,7}$ One aspect of

${ }^{6}$ Heinrich Berlin observed in the hieroglyphs of the Cross Group allusions to supernatural beings, which he called GI, GII and GIII, which would later be known as the Palenque Triad. ${ }^{35}$

${ }^{7}$ Stuart claims that there is no doubt between the identity of the GIII and the solar deity, but warns that beyond this general identity there is no clear evidence that the solar god is the jaguar god of the underworld. ${ }^{36}$ the solar god was that of Kinich Kakmo, "Fire Macaw Solar Face". ${ }^{3}$ In page 40b of the Dresden Codex, Kinich Kakmo appears with the head of a macaw and human body carrying a burning torch in his hand, representing drought and scorching heat ${ }^{34}$ (Figure 5). ${ }^{8}$ In Copán's ball game field, the markers are shaped like a macaw's head that alludes to the association of this bird with the sun during the Classical period. ${ }^{30}$ $K^{\prime}$ inich Ajaw is also associated with the deer, an animal associated with the peak of heat in Yucatan. ${ }^{1}$

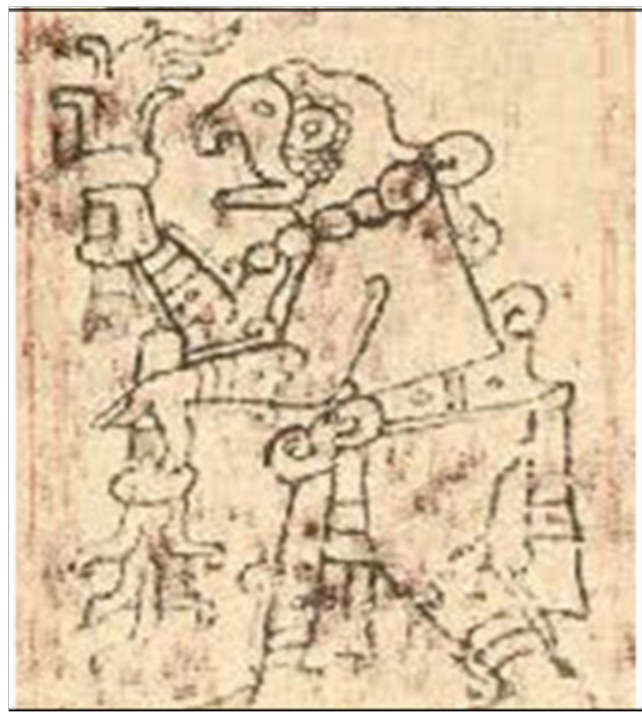

Figure 4 The solar god in its Kinich Kamo representation, the "Fire Macaw Solar Face". Dresden Codex, page 40.

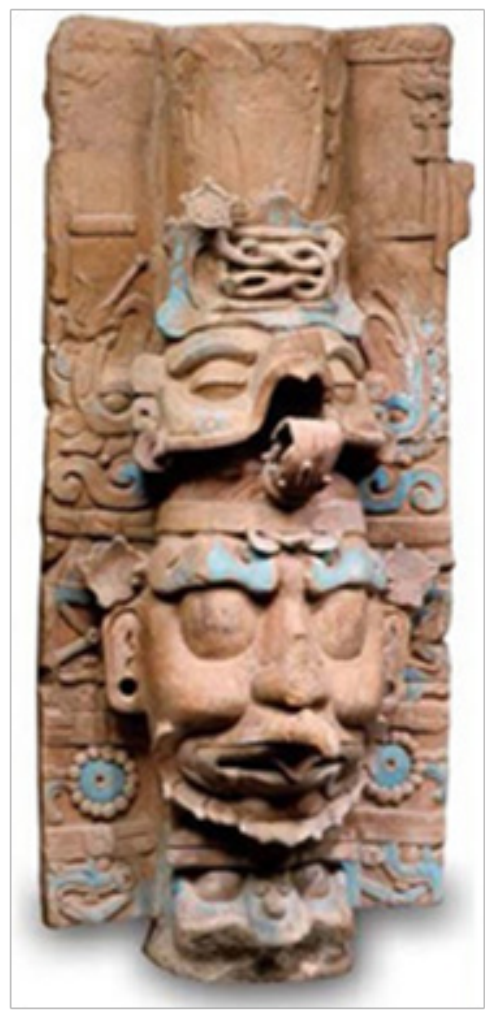

Figure 5 Censer from the Classic period displaying the face of K'inich Ajaw, Palenque, Mexico.

${ }^{8}$ In his interpretation of the Dresden Codex, Eric Velasquez agrees with Mercedes de la Garza in that the macaw for the Mayas was a relevant animal, since it was considered the incarnation of the fire of the Sun. ${ }^{34}$ 
The Mayan kings identified themselves with the sun, which was attributed with the male heat and territorial domination. And just as the sun governs the heavens, so does the king rule the earth. The rulers personified the solar god, in whom they saw a kind of paternal ancestor. ${ }^{5}$ An important title of the Mayan lords was kinich, "solar face". ${ }^{3}$ What did the Mayans think when they thought of K'inich Ajaw? The answer admits no doubt: They thought of him as the sun and, like the sun, they worshipped him. But, they thought of him in the category of the subject. The Mayan solar god was understood as if it were a person. Its task is, like that of any subjectivist force, to initiate actions or events, in this case to light the world and to continue its journey through the underworld during the night, facing a series of dangers. That is their raison d'etre. The condition that explains why this is so was already mentioned: the world is understood through the subjectivist scheme. For the Maya, it would not make sense to wonder if K'inich Ajaw is a god or a star. Due to the scheme that finds application in the perception and understanding of the world, the objects are understood through the concept of subject. In psychogenesis, the first concept of object that is formed is the concept of subject. According to this, the object schema carries the attributes of subjectivity and is the point responsible for the events it triggers. ${ }^{24}$

Once a cognitive schema has been constructed, it finds application as an operant mechanism in life experiences. Since the subject schema is the first to be constituted, it comes into force as a model of interpretation of all other objects and serves as a paradigm of all interpretation of reality. In this way, when the object's subjectivist scheme has been constructed, to make objects and events understandable, subjectivity becomes immanent to them. It is already in the very perception of objects and events and is not introduced to them in a later interpretation. Based on this scheme, objects and events are endowed with persons' attributes and human actions. This explains why the Mayans see K'inich Ajaw, the solar god, in the sun and understand its concealment at night as a journey through the dark and dangerous regions of the underworld. The Maya think of the subject when they perceive the natural elements. Of course, they realize that the sun is a sun and not a person, but they can only think of the sun, according to their scheme of thought, in the category of the subject. When it comes to explaining certain actions, such as solar activity, then the object-subject scheme suggested by the personalistic form is activated. Therefore, the Maya interpret reality in concepts of capricious beings, sensitive to words and acts, which can decide for themselves and refuse to cooperate with men, the sun can then choose to cause drought and end crops. For this reason, the solar god is also represented anthropomorphically in codices and it is said that he defeated, along with his twin brother, the dark forces that dominated the world at the beginning of time. ${ }^{36}$

\section{Chahk, the rain god, god $B$}

Chahk, the god of rain and lightning was one of the most venerated and popular gods, for the Maya believed to see in him the cause of the rains, hence the water essential for the crops. Karl Taube ${ }^{3}$ points out that the god Chahk is already present at the beginning of the classic Mayan religion ${ }^{3,17}$ and Stone and Zender consider that its longevity is greater than two millennia. According to Motul's Dictionary, Chahk was a very tall man who taught agriculture and whom the Maya had as the god of bread, water, thunder and lightning. ${ }^{37}$

Chahk was also the deity of lakes, rivers and seas and closely related, as well, with lightning and thunder. It is also associated with floods and droughts. ${ }^{1}$ It is the divinity most represented in the three
pre-Hispanic Mayan codices; its figure appears 218 times. ${ }^{38}$ In the Dresden Codex is represented 141 times, half of the total of all the images of the other gods. ${ }^{16}$ Chahk is depicted with a long, hanging nose, on which there is a volute-shaped element upwards; sometimes a fang sticks out from the corner of his mouth ${ }^{3}$ (Figure 6). He is also represented with a thick snout, as in Izapa's Stele I. ${ }^{17}$ Chahk was closely related to the snake, so sometimes his head is attached to a snake, or else he, in human form, rides a serpent, like in page 31 of the Madrid Codex $^{39}$ (Figure 7). In the codices and in the monuments of the Classic period, he holds an ax with a stone blade inserted on a wooden handle; the ax was a symbol for lightning. ${ }^{5}$ It was believed that he used it to open the skies to generate rain. ${ }^{1}$ The ax also refers to Chahk's original act, when, according to the myth, at the beginning of time he opened the mountain that contained the corn, thus providing humans' mode of subsistence, scene represented in a relief from Quirigua. $^{5}$

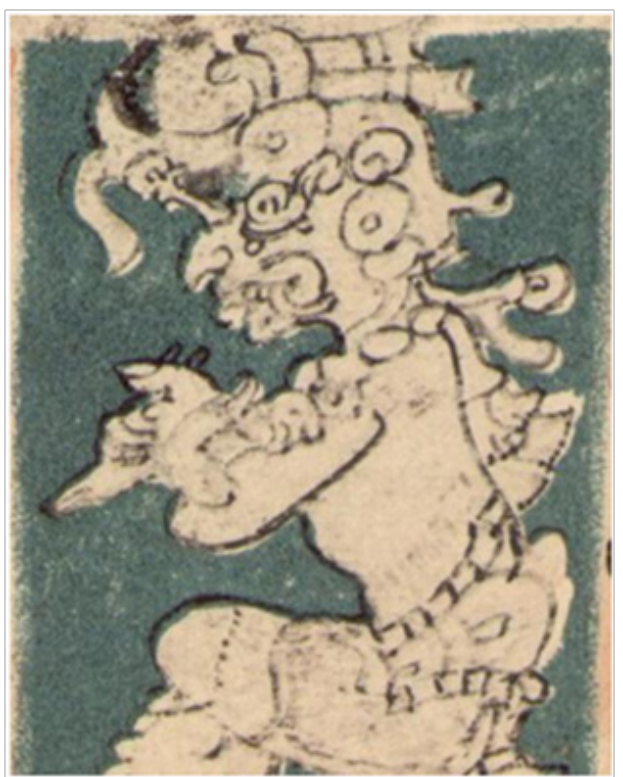

Figure 6 Chahk, Dresden Codex, page 40c.

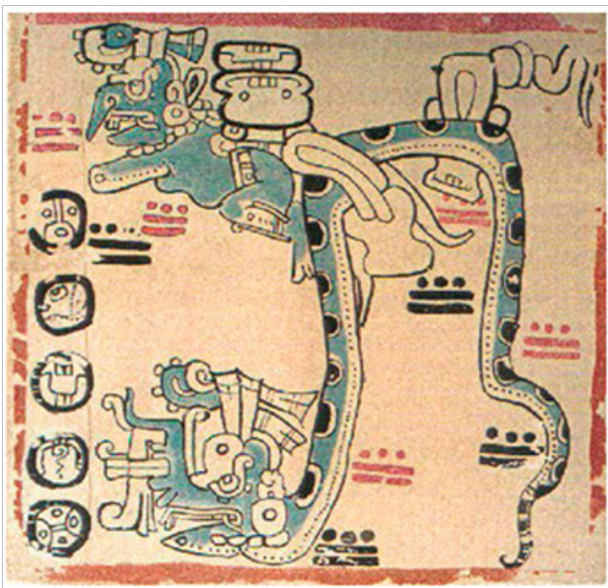

Figure 7 Chahk riding a snake. Madrid Codex, page 31.

The adornment he wears on his head is usually a headpiece that holds his mane and is made of seashell with a cross-shaped design in the middle. ${ }^{5}$ His body is always human, but sometimes it shows a serpentine aspect. He is sometimes depicted inside or above water, 
standing in the rain or on top of it, in a canoe, fishing 9 or hunting, or in the air, presiding over the clouds. It is also represented with a blazing torch symbolizing the scorching heat and drought, since it was believed that chahks oversaw both, the sending and retaining of the rain. ${ }^{16}$

The Maya understood Chahk as a single god, but also as the four gods of the cardinal points, each having its own color: Chahk Xib Chaac (the Red Chahk, Man of the East), Sac Xib Chahk (the White Chahk, Man of the North), Ek Xib Chahk (the Black Chahk, Man of the West) and Kan Xib Chahk (the Yellow Chahk, Man of the South). ${ }^{1,3}$ The set of Chahks is called Ah Hoyaob, "those who water" or "those who urinate". ${ }^{1}$ That's why, on some of the codices' images, ${ }^{10}$ rain falls from the legs of a Chahk. Like on page 37b of the Dresden Codex, which shows a Chahk urinating, ${ }^{34}$ In other scenes of the Dresden Codex and the Madrid Codex, the Chahks are seen pouring water with a clay pot. ${ }^{11}$ Izapa's Stela 1 suggests that in the Preclassic rain was considered Chahk's vomit. ${ }^{17}$

The Chahks were believed to reside in Chun caan, "at the foot of the sky," except when they occupied their positions on the world's cardinal points during the rainy season. ${ }^{1}$ In some images of the Dresden Codex, the Chahks are represented in the cenotes or astride them. The chahks glyph was a fist, with a jade bead on the wrist. The hand appears with a mouth and a barely developed nose. ${ }^{1}$ Chahks were associated with frogs, for it was believed their croaking announced the rains. On page 31a of the Madrid Codex, ${ }^{39}$ the chahks' figure appears surrounded by frogs that throw water out of their mouth (Figure 8).

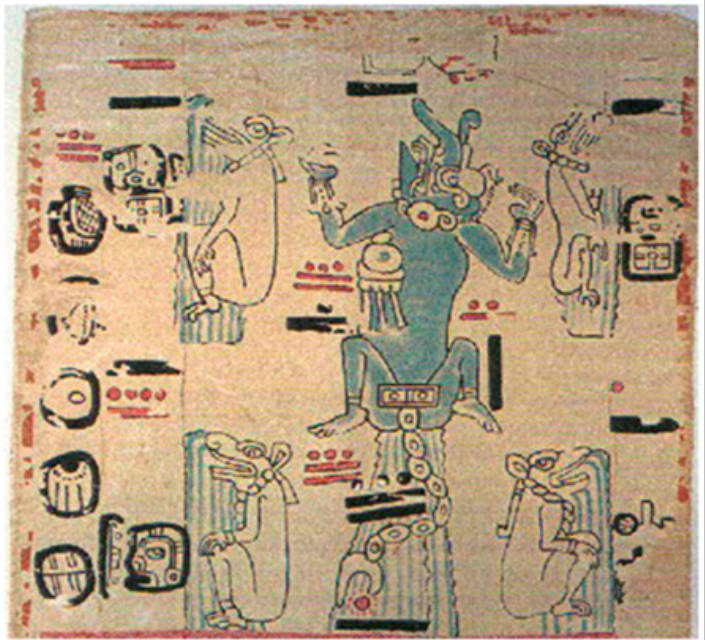

Figure 8 Chahk surrounded by frogs throwing water out of their mouth. Madrid Codex, page 31 .

To understand Chahk's the rain god personality and character, we must again consider the Maya's logic of thought, which they applied to the construction of the world. In early ontogenesis, every subject increases the coordination of his or her motor skills to interact with the outside world and especially with the person who takes care of him. With this, the category of causality is constructed simultaneously, since the relationship between subjectivity and action is a cause-effect

\footnotetext{
${ }^{9}$ Michael $\mathrm{Coe}^{40}$ points out that in both the Classic and the Postclassic, Chahk was often depicted as fishing, to see the images go to pages $44 \mathrm{a}$ and $44 \mathrm{c}$ of the Dresden Codex. ${ }^{3}$

${ }^{10}$ Madrid Codex 9b, 30b, 31a, 32b ${ }^{39}$ and Dresden Codex 37b ${ }^{34}$

${ }^{11}$ On pages $37 \mathrm{~b} 36 \mathrm{c}, 39 \mathrm{~b}, 67 \mathrm{a}, 74$ of the Dresden Codex ${ }^{34,41}$ and pages 9b, 13a, $14 \mathrm{~b}$ of the Madrid Codex. ${ }^{39}$
}

relationship. When applying this structure in the interpretation of the world, the cause of the event turns out to be the subject. Just as in the scheme of action the only force capable of set it in motion is the subject and, along with him, subjectivity, in the understanding of the world that is based on this scheme, the subject is the force with the power to start the phenomenon. If in the Mayan world someone ever wondered what caused the rain, the sages did not hesitate to give the answer: when urinating or throwing water with a pitcher, Chahk is who makes the rain.

We cannot overlook that, structurally, the explanation of the natural phenomena that is based on the subjectivist logic gets inverted: generally, the action happens when the actor conceives a plan and tries to carry it out. Action starts from the subject, continues its course in the world as a phenomenon and finally reaches its goal. From the perspective of the actor himself, or whoever interprets his action, the action goes from the actor to the goal. No matter what the reasons are that determine the action, this always results from the subject. However, when it comes to understanding a phenomenon in the world, the process is reversed: thought starts from the phenomenon before it, travels the path in the direction of an agent's subjectivity and then causes it to emerge from it. For this reason, when this scheme finds application in explaining the rain or lightning, these can only be understood as a consequence of a powerful subject: Chahk.

\section{Itzamnaaj, the creator and god of heaven, god D}

The Maya believed in a creator god, who took the place of the supreme god in the Mayan pantheon. No doubt, it was the most important deity. ${ }^{5}$ Itzamnaaj was the creator deity in the cosmogonic myths, the world's fecund energy, manifested itself in many ways and had different names. In the codices, his appearance is that of an old man, with an aquiline nose, large square eyes and toothless jaws ${ }^{1}$ (Figure 9). In the images that represent him appears as a priest or as supreme ruler. In the Madrid Codex, he is represented as a priest with a miter on his head and a black cloak, probably the chasuble described by the colonial texts. ${ }^{3,39}$

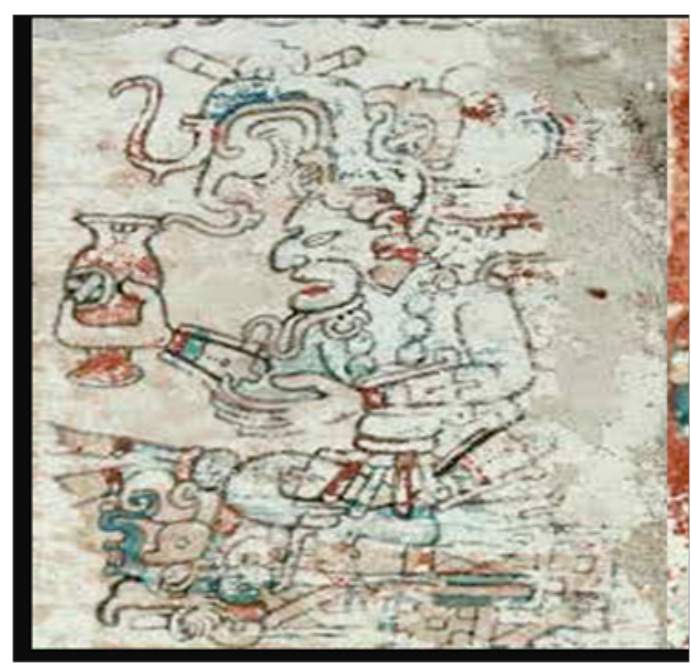

Figure 9 Itzamnaaj, Dresden Codex, page 46.

The Relation of Valladolid refers to Itzamnaaj as the heavens' supreme ruler, or ah tepal. ${ }^{3}$ In Quiriguá's Stela C, he is mentioned as an actor of creation and founder of the dynasties at the beginning of the last baktun in $3114 \mathrm{BC}^{5}$ and the inscriptions in Palenque's temple XIX reveal that he presides over the assumption of GI to the 
lordship. ${ }^{35}$ In them, Itzamnaaj supervises the enthronement as if he himself was a high ruler, or, at least, as a character hierarchically superior to the GI. ${ }^{35}$ Iztamnaaj's role as creator god and supreme chief was depicted in art, where he often appears sitting directly in the sky or on a throne covered with jaguar skin (Figure 10). Sometimes he is presented on his throne on top of a tall mountain, or receiving visitors or messengers. ${ }^{5}$ His name has two hieroglyphs, the first is formed by the face of the deity itself and the second contains a shield or a mirror as its main element, which means "king, emperor, monarch, prince or great lord", so it is safe to assume that Itzamnaaj's second hieroglyph refers to his position as the supreme god of the pantheon. ${ }^{5}$

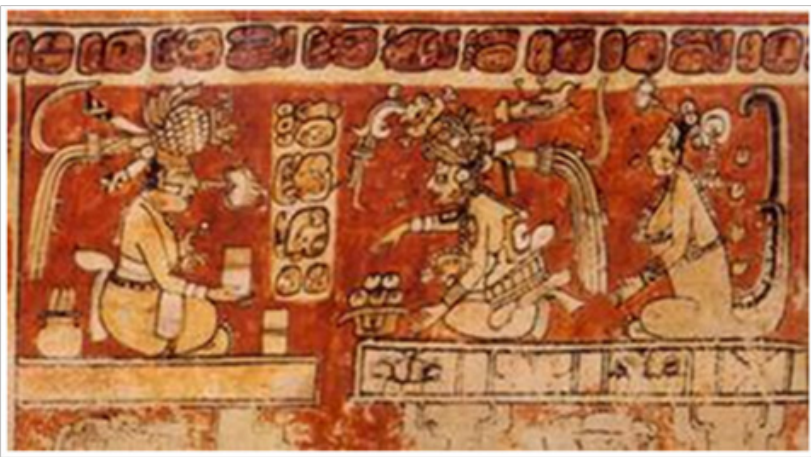

Figure 10 Itzamnaaj in his celestial court.

There is reason to suppose that in both the Classical and the Postclassical, Itzamnaaj was considered an omnipresent deity that resided in both heaven and earth. ${ }^{3}$ As Lord of the Sky, Itzamnaaj sent rain, duplicating the activity of the Chahks. In one of the colonial sources it is said of him: "The ancients had a most celebrated idol, Ytzamat $u l$, which means he who receives and possesses the grace, or dew, or Heaven's substance they say that this was a king, great lord of this land, who was obeyed by the son of Gods: and when they asked him what his name was, or who he was, he did not say any more than these words: I am the dew and the substance of Heaven and clouds". ${ }^{42}$ When the Maya asked for abundant crops, they addressed to Iztamnaaj, saying: "Great Lord of sky and who is set in the clouds and in the sky., ${ }^{3,43}$ The Maya collected the dew from the plants, in which they perceived the presence of Itzamnaaj, to use in their rites and ceremonies. ${ }^{3}$ There are several paintings that represent him as a priest sprinkling dew with the help of the sound of the rattlesnake $e^{3,39}$ (Figures 11) (Figure 12). One of its attributes, the band adorned with beads from which hangs a floral motif, is known as itz, a Mayan word that means nectar and dew, semen, tears and resin. $3,5,16,44$

Itzamnaaj was associated with the world tree as well, the central axis that united the sky, the earth and the underworld. On the tombstone that is in of the tomb in the Temple of the Inscriptions, in Palenque, the cross, axis mundi, is Itzamnaaj himself, who leans on a figurehead that represents the terrestrial monster. ${ }^{30}$ In the iconography of the Classic, he often appears with the sacred trees, as in the late Classic's vessel 108 , on which he appears in front of the alligator tree. ${ }^{45}$ Itzamnaaj was also attributed with the invention of writing and the calendar. Lopez de Cogolludo mentions that the Maya during the conquest saw in Itzamnaaj the priest who named all the sites of the earth ${ }^{14}$ which, for a mind that is convinced of creation through the word, is equivalent to recognizing Itzamnaaj as the creator of all things. ${ }^{12}$ Itzamnaaj was associated with wisdom, esoteric knowledge and divination, which

${ }^{12}$ In many cosmogonies, language is associated with creation, to name things is to give them being. manifests in his name. Barrera Vázquez translates itzam as "warlock or water wizard", while Na means to contemplate, to understand or divination. ${ }^{44}$ In the high lands of the south, itz is the root for witchcraft and everything related to divination, Itzam would be the person who incarnates or manipulates itz, some substance, or magic force. ${ }^{12}$ It is likely that for the Mayans, just as for all Mesoamerican peoples, the primordial and fundamental act of witchcraft was the very creation of the universe. ${ }^{12}$ On some pots from the Classic, Itzamnaaj appears related to the writing arts ${ }^{20}$ in one of them coming from the late classic Itzamnaaj appears teaching writing. ${ }^{45}$

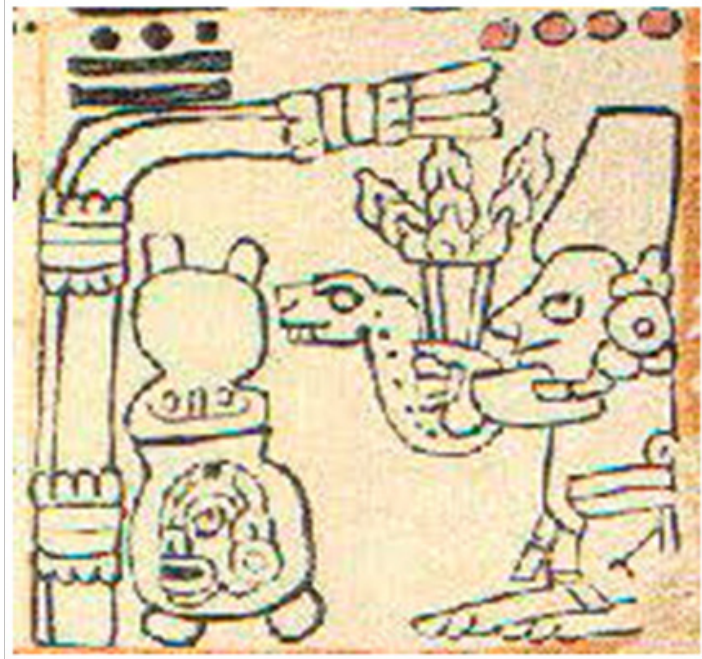

Figure I I Itzamnaaj as a priest, with “miter”,"chasuble”, and “hyssop”. Madrid Codex, page I00d

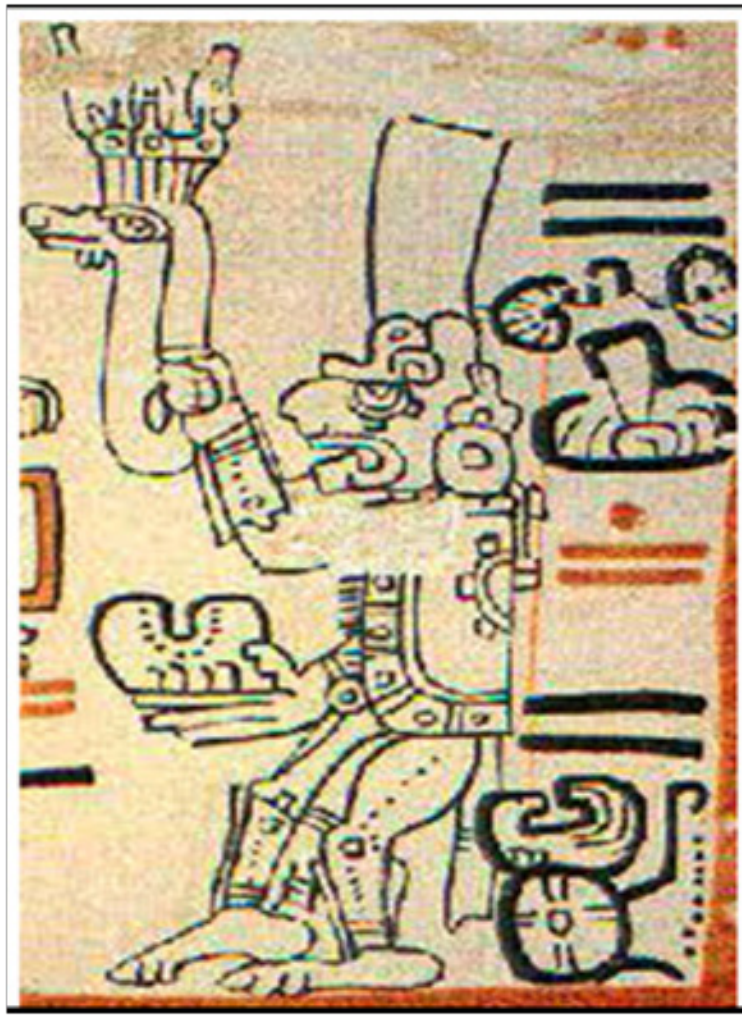

Figure I 2 Itzamnaaj as a priest, with “miter”,“chasuble”, and "hyssop”. Madrid Codex, page 106a. 
Itzammaj was also associated with the four Bacabs, the holders of the sky. ${ }^{12,46}$ The Chilam Balam of Chumayel relates how the holders of the sky destroyed the previous world, by letting the sky fall. The catastrophe appears in a scene from the Paris Codex. It is the same sheet that introduces the New Year, in which you can see the four old holders of the sky, identifiable by their headdresses. They are seated on the celestial band and with their arms around their knees, which infers inactivity. The scene is surrounded by giant serpents, which show in their body the hieroglyph for the eclipse, with the gods dead in their jaws ${ }^{20}$ (Figure 13).

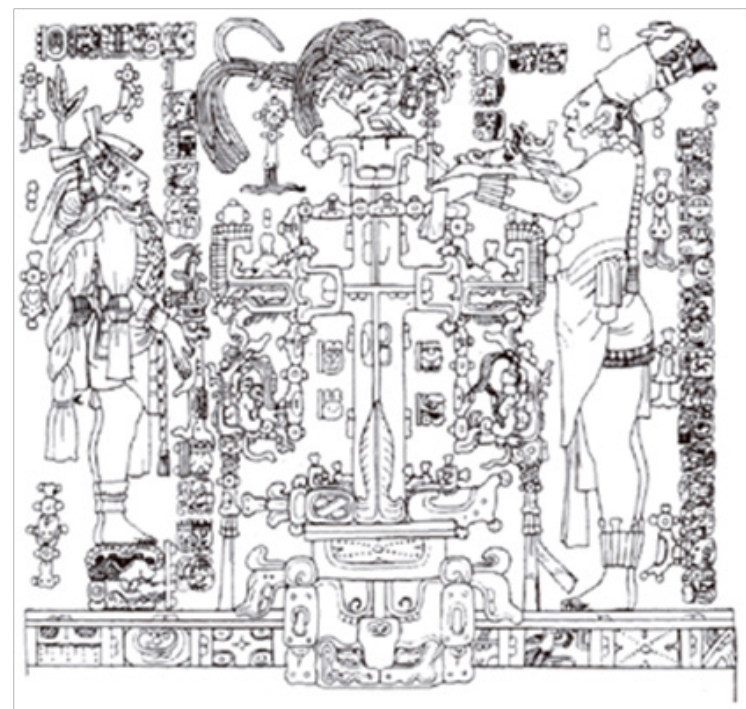

Figure 13 Itzamnaaj on the board of the Temple of the Foliated Cross.

Diego de Landa's text explains that the Bacabs managed to escape from the last hecatomb, caused by a deluge and that later God ordered them to hold the sky so that "it did not fall". Each one of the Bacabs was destined to a part of the world and was made responsible for each of the years that comprised the four years Mayan cycle. Each Bacab had "marks of the miseries or happy events that were to happen during the year". ${ }^{47}$

\section{The logic of the supreme god}

The Mayan conception that considers Itzamnaaj the origin of the cosmos presents the same framework that allows the existence of the other gods. The difference resides in that the object of thought is the entire world and not particular phenomena. We have seen how the Mayan gods are the result of the application of a schema of interpretation of reality, the subjectivist logic. Because of the conditions in which the cognitive schema formation process occurs, the mind (thought?) assigns a subjectivist center (core?) to objects when it perceives and interprets reality. At the level of worldview (cosmovision), this not only happens before natural objects, such as the sun or the rain, but also for those that represent a unit in themselves, like the world as a whole. The cosmos is then understood through the same scheme, which is applied to understand to understand specific phenomena. As the Maya reflect on the world, it is understood through the cognitive structure and attributed to an agent, Itzamnaaj. In a strict application of this logic, when contemplating a world in its entirety, its origin can only lie on a single god.

If we ask ourselves then about the reason for the rise of a supreme god in the Mayan belief system, it is important to point out that he emerges when the mind reflects on the entire world, regardless of its possible limits. A god's standing depends on how important the event it's responsible of is for the people that believe in him. Therefore, if Itzamnaaj is responsible for the order in the cosmos, then he is most important god. However, what is the world present in the Mayan mind? Does their idea about "the world" coincide with that of the monotheist religions or ours? The Mayan vision of the "world" or "cosmos" is the result of the existential need to comprehend the whole and categorize its unit, accompanied by the fact that mankind sees itself immersed in a network of wider relations. The Mayan cosmos was a spatial model that encompassed both the earth and sky and, in some cases, the underworld, where humankind's life took place on the earthly plane, but where forces of the sky and, eventually, the underworld's, exerted their influence on it. It is possible that the idea of a stratified cosmos was reinforced through the observation of the Mayan geographical area, which comprised many cenotes and caves. The Maya surely must have observed that under the earthly plane existed rivers and underground caves that formed a lower plane.

For the Maya, their world was the world. The faraway lands or foreign men were completely irrelevant. And given that the structure of thought compels them inevitably to consider the origin of things for the logic of action always arises from the subjectivity the Maya thought about the cosmos and its creative force, making the cosmos coincide with a god, Itzamnaaj. Within their world, their supreme god assumed a sort of universal jurisdiction or competence. Once a deity was recognized as the original cause of the origin of the world, every explanation was referred back in last instance to the initial cause. Hence, it's not surprising that Itzamnaaj is ascribed with more attributes; the rain is attributed to him, same as earth's fertility; he is considered a warlock or priest, or as the supreme ruler.

\section{The logic of the creator god}

Yet, the Maya did not only conform themselves with considering the world as a whole and conceive a deity in it responsible for everything that exists, but they reflect on the world order they associated with the processes significant to them: the day and night, the dry and rainy season, the earthly and heavenly planes. To explain this order, they developed cosmogonies. For the Maya, as mentioned, the primordial world order corresponds with a spatial order where the sky is up, the earth in the middle plane and the underworld below. Mayan cosmogony certainly not the only one tries to answer the question: how was it possible for these cosmogonic planes to separate themselves spatially in such a way that made human life plausible? Their idea of chaos, that is, the stage of darkness prior to creation, referred to a stage where these levels overlapped. Creation is the introduction of a cosmic model, which divides the planes, reason why the creator god is responsible for raising the sky and eternally holding it up. Therefore, the creator god is a quadripartite god; each of the gods holding the sky Itzamnaaj's unfoldings is responsible for keeping up one of their four parts. ${ }^{12}$ This is also represented in the design of Palenque's censers, which were used in ceremonies and seen as cosmic trees where the earthly, under worldly and celestial levels were represented. ${ }^{31}$

The logic of thought also contributes to explaining Itzamnaaj's central role. In the logic of action, the subject is always found in the middle of the field of action. Because the actor and with him subjectivity, creates his own space to act through his action, he is under the impression to be right in the center. When this scheme is applied at the world interpretation level, the god that undertakes 
creation necessarily appears occupying the central place. Because of the logic the thought is based upon, the center turns as well into a place where the creation of the universe is contained and, as a result, space and time. In the Maya worldview, the supreme and creator god is then related with the tree that occupies the central position in the universe and extends all the way from the underworld to the heavens. However, Itzamnaaj had other aspects we must analyze.

\section{Itzamnaaj and the principal bird deity}

Itzamnaaj, like the world tree that extends from the earth to the sky, is associated with both. ${ }^{3}$ During the Classic, the figure of Itzamnaaj merged with some of the sky dwellers, among them, the Principal Bird Deity. ${ }^{13}, 12$ The image of this deity shows a long lip and some sort of bird wing displaying the profile of a snake head. ${ }^{3}$ In general, it appears with large and long feathers, short legs with spurs and a mirror symbol at the tip of the tail. Its image sometimes appears with headdresses, tufts, hairstyles, head bands and decorative elements in the ears.

In some cases, Itzamnaaj assumes the form of a bird completely, which wears a headdress bearing the signs of the night and the mirror ${ }^{1}$ (Figure 14), while in others, the Principal Bird Deity appears with only some of Itzamnaaj's attributes and, conversely, the supreme deity shows the traits that characterize its avian invocation. The clearest visual link between Itzamnaaj and the bird are the arms of the heavenly ruler in the form of feathered wings. ${ }^{12}$ Sometimes the name of Itzamnaaj is preceded by muut, "bird". ${ }^{12}$ There are also many images that show Itzamnaaj and the Principal Bird Deity as two autonomous beings, but closely united in some contexts ${ }^{12}$ (Figure $15) .{ }^{14}$

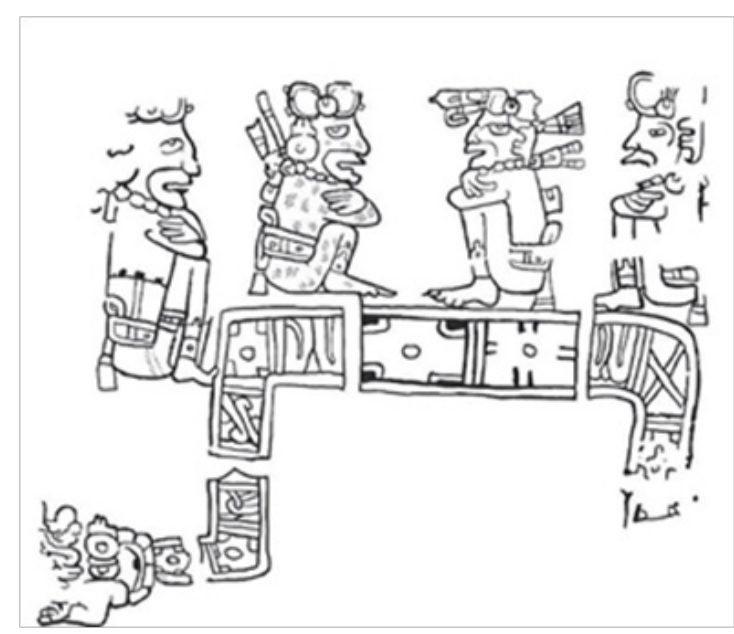

Figure 14 The four gods, Itzamnaaj's quadripartite representation, and the collapse of the sky. Paris Codex, page 22.

This association between Itzamnaaj and the Principal Bird Deity remained until the late Postclassic, although at the beginning of this period Itzamnaaj's humanized figure, especially as an elder, was also generalized. ${ }^{1,3,11}$ In other images, the Principal Bird Deity appears perched over the body of a snake made of clouds. ${ }^{48}$ Itzamnaaj's relationship between his avian invocation and the snake is probably

${ }^{13}$ Lawrence W Bardawil gave the name of Principal Bird Deity to the bird with the most prominent position in Mayan iconography. It often appears on top of the tree or the cosmic monster. Bardawil himself suggested it might be the avian manifestation of Itzamnaaj. ${ }^{48}$

${ }^{14} \mathrm{On}$ the fusions of the Old man (identified with Itzamnaaj) and the Principal Bird Deity, see. ${ }^{12}$ due to the generalized homophony between the terms "serpent" and "sky" that exists in the Mayan languages, the snake head emphasized the celestial essence of the bird. ${ }^{49}$ In Yucatec Mayan kan means "serpent", ka'an means "heaven" and ka'anil "something celestial", so the snake head could have been placed in the wing of several birds to accentuate the notion of "sky". Martin emphasizes that the Principal Bird Deity was the most frequent invocation of Itzamnaaj and points out: "As we now know, the affiliations of God D are not saurian but avian, a decisive blow to the model". ${ }^{12}$

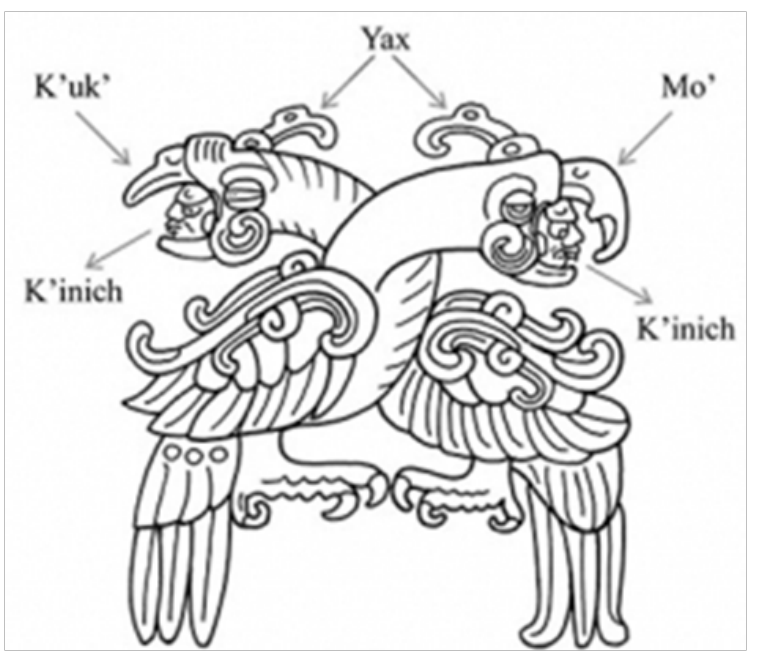

Figure 15 Itzamnaaj conjoined or fused with the Principal Bird Deity.

Several authors ${ }^{40,49,50}$ agree that it is Vucub Caquix, or Seven Macaw, the great monster bird of the Popol Vuh which according to myth usurped the role of the sun and magnified itself. ${ }^{15}$ In important sites, the Principal Bird Deity appears as a majestic being, occupying the central position in the world, like on Palenque's Temple of the Cross panel, where it perches on the world tree or on the Temple of the Inscriptions' sarcophagus tombstone; or on the Temple of the Foliated Cross' tombstone. To date, it has not been possible to identify which species the Principal Bird Deity belongs to. Some early sources link Itzamnaaj to a bird called Yax Cocah Mut, which researchers now extend to the Principal Bird Deity. In Tzeltal, kok mut designates the harpy eagle, one of the largest birds in the world, so it is likely that the Principal Bird Deity is related to this species, ${ }^{12}$ but deeper studies are needed to assert definitively that there is an identity between both.

The Principal Bird Deity has been described as a manifestation, avatar, aspect, or messenger of Itzamnaaj, so far remaining unclear what the nature of the relationship is. However, before understanding the link between the supreme god and this fabulous bird, we must keep in mind how the Maya perceived the qualities of an object. An object is defined by the specific way in which its qualities are combined. However, when these characteristics are seen through the structure of thought, the scheme of action, they are conceived as if they were linked to a nucleus, a center. This could also be our idea of object, if we appreciate the permanent qualities of the object as a center that constitutes its substance or essence, but, in Mayan thought, the way this center interacts with the peripheral features is determined by the cognitive structure. Hence, the relationship between the center and the periphery, that is, the external characteristics, bears resemblance to the relationship between subjectivity and its manifestations. That is why the mind conceives the features of an object as if they originated

${ }^{15} \mathrm{On}$ the representations of this episode in vessels and stelae, see. ${ }^{49}$ 
from a center behind them, from where they originated and which they remained linked to. In the same way that action results from intangible subjectivity, which it depends on at all times, qualities such as color, form, etc., are seen as emanating from a subject/substance which they remain attached to. ${ }^{29}$

Nevertheless, objects are not static. Some qualities are a set part of the object, others are temporary. A plant grows in the earth, has spines or flowers, it fills with leaves and it dries up. A duck walks or swims. In the Mayan thinking, these dynamic qualities as well as the fixed traits are perceived and understood as in a relationship between a substance/subject and the qualities. This relationship leads to establishing a partial identity between them. Qualities are perceived as manifestations that materialize the center that integrates and determines them. In this way, objects or phenomena are conceived as signs of a power that is within or behind them. It is as if a nucleus as an integrating substance was attributed with the ability to present itself in this or another way.

This way of appreciating qualities contributes very significantly for the Mayan world to be a world understood as the manifestation of a reality that is behind and that determines it. Events and objects are perceived as the visible form of invisible entities or essences, in them they have their origin and to them they remain linked. The relationship between Itzamnaaj and the Principal Bird Deity is established through an important trait: both travel the sky. Mercedes de la Garza, referring to the link between the celestial deity and the bird, expresses with admirable sensitivity the look most Maya must have had when they reflected on it: "The celestial vault appears before the religious man as something totally different from his terrestrial space; It's what is transcendent, the absolute reality, strength, continuity, the source of light and life, the source of good. Through the sky, a place inaccessible to man, travel for the believer the sun and the stars, generators of light, order and regularity of the universe, creators of cosmic temporality; and from heaven also come the primordial energies of life, which allow life on Earth: water and solar heat and fire along with them, essential for the life of man. Most of the creator and essential gods, beginning with the supreme deity, are in heaven. ${ }^{51}$

For a supreme god, ruling the sky is an attribute that stands out among all other qualities. On his hands is the existence of the universe, order, the eternity of cosmic rhythms and, thus, the structural and social orders. Thanks to these powers, Itzamnaaj was not only able to realize creation and ensure its continuity, but also preside over the enthronement of the Mayan kings. Regarding the bird, de la Garza points out: "... an earthly being who is able to ascend to the heavens by its own nature, like the bird, is par excellence sacred; it can be the very incarnation of the divine, or else an epiphany, the vehicle through which the gods manifest themselves; likewise, the bird is a demiurge: the being that communicates with the gods and transmits their messages through its peculiar language". ${ }^{51}$ The fact that an earthly being can rise to heaven brings it share a characteristic with the supreme deity: the ability to move through the levels of the cosmos. The Maya imagined that Itzamnaaj could move between the different planes of the universe the sky, earth and underworld and because of this life on earth was possible. ${ }^{31}$

In addition to the ability to move between the earthly level and that of heaven, in other words, the ability to travel between the dwellings of the gods and the world of men, other qualities strengthened the relationship between the supreme god and the bird, such as its proximity to the sun, the beauty of the birds' wings and the aggressiveness of some birds, such as eagles. In the Mayan representations of the Principal Bird Deity, the beak and wings are accentuated, suggesting what traits may have been important to them. To these common features, we must add the fact that the Principal Bird Deity was considered a celestial bird that held the highest position in the hierarchy of birds, similar to Itzamnaaj, who was thought to occupy the highest position above all the living creatures. ${ }^{52,53}$

Of course, the Maya knew birds were no gods, but the scheme through which they understood and explained the world forced them to understand that behind the objects and phenomena was the divine level that shaped them. Their presence became tangible through the objects' attributes of the world they lived in. Therefore, where the same qualities were present, it was thought of a substance that was their own. If the bird is capable of travelling from the earthly to the heavenly level, it also must have the divine force of the subject/ substance, which manifested itself in the trait and, therefore, was (partially) identical to it.

\section{Itzamnaaj as a celestial and terrestrial monster ${ }^{16}$}

The Classic Maya related Itzamnaaj with the celestial monster and the rains. His image in the Classic is sculpted on doors, stone monuments and stucco panels, as well as painted on the walls and polychrome glasses of the elite. ${ }^{48}$ The body of the monster located on the inner entrance of Copán's Temple ${ }^{20}$ is made of clouds. ${ }^{48}$ Iconography often shows the head of the cosmic monster pouring out liquids, which, with certain complementary signs, can be identified as blood, or, as on page 74 of the Dresden Codex, as water. ${ }^{12}$ Sometimes, the body of the celestial monster takes the form of a celestial band with astronomical signs and during the Classic period there are stellar symbols where the eyes should be. ${ }^{12}$ Several Maya researchers argue that Itzamnaaj's representation of as a cosmic monster is associated with the Milky Way when it extends through the heavens from east to west. If the Milky Way runs north to south, it is represented by the figure of a ceiba or cosmic tree. ${ }^{52,53}$

The presence of celestial bands with eclipse hieroglyphics and various beings ${ }^{17}$ on the stellar serpent's body connect the cosmic monster with the Ecliptic. ${ }^{52,53}$ The most obvious example of the Ecliptic identity (connection?) with the cosmic crocodile is the flood scene on the Dresden Codex, where not only does it have a celestial band body but eclipse glyphs as well, a phenomenon that only takes place on the Ecliptic. ${ }^{48}$ This identity is also based on the frequent images depicting the cosmic monster with the quadripartite monster as its rear head, a manifestation of the sun, while the anterior head is linked to Venus. Since the sun is on its head, Velasquez suggests that the load it carries across the heavens is the cosmic monster, identified in this case with Venus. ${ }^{48}$

\section{Itzamnaaj as terrestrial monster}

The monster that represents Itzamnaaj also has a terrestrial or under worldly aspect: Itzam Cab Ain, "Cayman of Earth Itzam", which represents the earth ${ }^{56}$ and assumes a prominent role in the narratives of creation. In the Mayan region the great crocodile was a

${ }^{16}$ In Mayan research, there is no homogeneity in the attribution of this figure. Mercedes de la Garza refers to it as "celestial dragon", ${ }^{11}$ Erik Velasquez as "cosmic monster or caiman", ${ }^{48}$ but also as "stellar deer crocodile". ${ }^{54}$ Ernesto Vargas and Teri Arias mention it as "crocodile or lizard". 55 Taube calls it "caiman". ${ }^{56}$ According to Martin, the stellar monster has received more than a dozen denominations in the Mayan studies. ${ }^{12}$

${ }^{17}$ Among them, Venusian descending god on page $58 \mathrm{~b}$ of the Dresden Codex. ${ }^{34}$ 
very widespread symbol of earth. This crocodile is the one that appears on page 4 of the Dresden Codex, where the god's face emerges from the jaws of a two-headed crocodile ${ }^{1,3}$ (Figure 16). The Maya believed that the world was seated on an enormous caiman or lizard and that it, in turn, floated on a vast lagoon. ${ }^{3}$

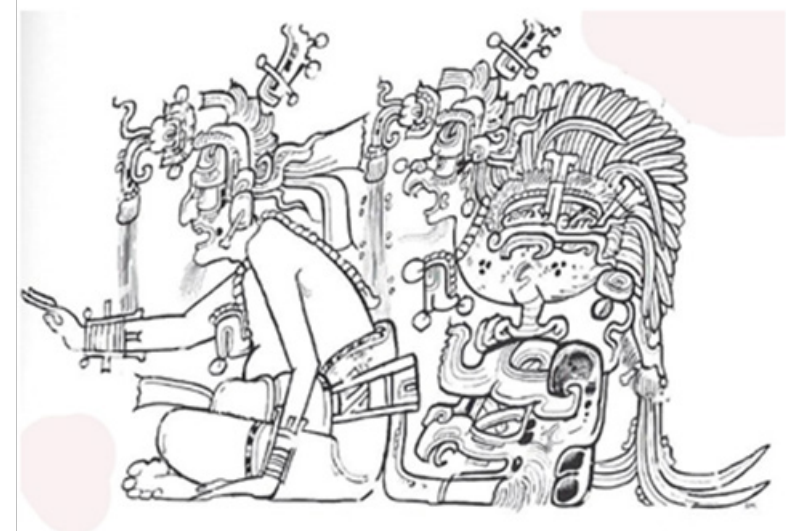

Figure 16 Itzamnaaj and the Principal Bird Deity as two separate beings. Photo of Michel Quenon, Coe, and Houston 20I5;PI. 18

There is clear iconographic evidence that shows the identification of Itzamnaaj with the terrestrial crocodile during the late Post-classic. One of them is the figure excavated by Thomas Gann in Santa Rita, as well as the well-known mural 1 from the same town, in which the gods of the tun cycle stand on the body of a crocodile floating on the sea. ${ }^{56}$ Itzam Cab Ain played an important role in the myths of creation, for they used its body to make the earth after killing it. ${ }^{12,57}$ The myth begins with a cataclysm caused by the saurian after vomiting the fluid that floods the earth. Then, the gods decapitate the reptile to stop the flood. Later, the body of the lizard falls on the earth and on its four corners are placed the four world trees to raise and hold the sky that had collapsed. ${ }^{46}$

Colonial sources tell that after this, a supernatural being called Uuc Chekna, 1 from the seventh layer of the earth, descended and stepped on the backs of Itzam Cab Ain. ${ }^{57} \mathrm{~A}$ remnant of this myth survives in the Popol Vuh, where the hero twins trick a monster named Zipana into a cave, where they trap it and turn it into stone. ${ }^{12}$ In its incarnation as Itzamnaaj Cab Ain, the supreme god also had a vegetable aspect, Itzam $\mathrm{Na}$ Kauil, which accentuates the hidden generating power within the earth, which was attributed to Itzamnaaj. ${ }^{16}$ This can be seen in the Panel of the Foliated Cross of Palenque, where the "tree" (a maize plant) emerges from the head of the earth as a land dragon, a manifestation of Itzam Na Kauil. ${ }^{16}$ Itzamnaaj's glyph is not only characterized by the long serpentine nose, but also by the foliage that sprouts from the forehead. In some cases, it takes on the form of a vegetable ornament, occasionally with corn kernels. ${ }^{16}$

Itzamnaaj was also associated with fire. ${ }^{3}$ In the formulas recited to cool hot water, the hearth stones are called the head of Itzam Cab; the logs are its thighs, fire its tongue and the vessel above it its liver. This is confirmed by archaeological evidence, for the head of Itzam Cab sometimes carries the glyph of fire in the headdress. ${ }^{16}$ In addition, in the myths it was said that once the earth monster was killed, it was burned. So, the Maya performed a ceremony in which they painted a terrestrial monster and then made a fire on its silhouette. Later they stepped or ran on the hot embers, symbolically renewing time and the world. ${ }^{18}$

${ }^{18} \mathrm{~A}$ colonial text reads as follows: "They also heard of the fall of Flood Lucifer, and that the world was to end by fire, and, in consequence, they would perform a ceremony and paint a lizard which represented the flood and the earth". ${ }^{43}$
We have already explained how, according to their thinking structures, the Maya understood qualities. This also applies to understanding the relationship between the supreme god Itzamnaaj and the terrestrial monster. Vargas and Arias point out some of the characteristics of the crocodile that link it to the supreme god: "The life of the crocodile is linked to water, which fecundates everything, is a primordial element, through it it's possible to be born and reborn, to be purified, gain life, vigor and eternity. What can be inferred from this fertility and rebirth process is that the crocodile is associated with the celestial plane. The crocodile can submerge and be reborn, it does not die, but returns from the origin and the origin were created by the celestial gods, he gives life that is also celestial and fertilizes like rain. ${ }^{55}$

The Mayas perceived the presence of the supreme divinity in the fixed and dynamic qualities of the crocodile. For with the supreme deity it shared the possibility of being reborn, after "dying" submerged underwater. With this highly significant trait it showed that it had the enormous power to generate life, to beget itself. And, since only the supreme god had the sacred power needed to give and generate life, the lizard or crocodile was considered as divine. In it, in its capacity to give itself life manifested the sacred power of the divinity to set in motion the life-generating force. A quality proper of absolute origin and therefore contains all the other qualities attributed to divinity.

But, did the Maya see a deity in the crocodile or lizard? The answer is no. Their understanding and perception of the world allowed them to clearly separate between the divine and earthly planes. However, they perceived, in certain objects or phenomena' qualities from the tangible world, the presence of the sacred forces that determined what happened in the world. Specific qualities of an object or phenomenon were understood as originating from a subject that was behind them, to whom they remained linked and who they related with some deity. Therefore, where certain qualities were present, they thought of a subject which they belonged to. If the crocodile was credited with the ability to resuscitate, that is, setting in motion the force that generates life, it must then have the very force proper to the supreme divinity.

Yet, where does the relationship between the main deity and the terrestrial monster come from? In the Maya thinking, the origin must explain the substantial side of what exists. In its substantiality, the world must be derived from it. Some researchers start from the idea it is important to specify if in a religion creation occurs from nothing without some sort of preexisting matter or, on the other hand, if creation results from the activity carried out by a creator god in interaction with a preexisting material, which only has to be processed or processed. But this approach to the belief system does not correspond to the structure on which thought is based in early cultures. The origin, understood under the logic of action, is always subjectively conceived as material.

For the Maya, the origin is both the creator god Itzamnaaj and the terrestrial monster; from the latter comes the earth's material substrate. Their interest in myths is that their model of explanation includes the world as a whole as well. To do this we must go back to a state prior to creation and name the active principle that allowed the existence of the cosmos. Due to the thought structure, an origin which contains already what is to come out of it must be assumed and also that which is already given and from which will emerge what will later constitute the present world. The Maya imagined this original substance like a monster or crocodile that inhabited an original lagoon. If we want, one can say that before the existence of gods, men and things, there was only the monster floating on a sea. ${ }^{8}$ But it cannot be inferred from this that the myth that speaks about earth's formation is a 
materialistic construction, even though at the beginning the crocodile is already present in the middle of the lake, it is perceived through the subjectivist scheme. Only thus can it contain the active principle that causes the earth to arise from itself. And indeed, the Mayans thought the original caiman was also the primordial god, Itzamnaaj, as shown on page 4 and 5 of the Dresden Codex, in which the head of the deity emerges from the monster's jaws.

For the Maya, it is not that the reptile was found simply in the middle of the water, but rather that this was thought of beforehand in the subject's category form. And precisely because of this, Itzamnaaj Cab Ain became a deity. Did the Maya think of the beginning as a crocodile or as a god? This question is totally inadequate, for his thought could only understand the object and the subject as one. Wherever this understanding is expressed explicitly, both express themselves without problem as a single being, as shown by the representations of Itzamnaaj poking his head from the open jaws of a crocodile.

In myths that refer to the sacrifice of the crocodile, whose body is then used to set solid ground, the animal is only the substantial part of the origin. The creator god is the subject who assumes the active role of creating the earth. The subjectivist schema of thought forces us to think of the origin both subjectively and substantially. Like action, which derives from both the subjectivity and the actor's material body, the origin has a side linked to the object and another to the subject in the logic that emanates from it. In Mayan cosmogony, at the beginning of the world the creator god is the one who undertakes the cosmic work of creating the earth, while the terrestrial monster is the substantial part from which derives the very materiality of it.

\section{The creative couple itzamná and ix chel}

While Itzamnaaj was the most important Mayan deity, who was credited with the origin and conservation of the world and not a few other benefits for the life of humankind, some sources suggest the Maya followed the Mesoamerican conception and this deity had a female counterpart. ${ }^{12}$ As shown on pages 75 and 76 of the Madrid Codex ${ }^{39}$ the Maya believed that the gods of creation were a divine couple: Itzamnaaj and Ix Chel, who occupied the center of the universe, underneath the world, tree (Figure 17). Las Casas affirms that he heard the natives say an almighty god named Itzamnaaj, son of the god creator of the world, married a goddess named Ixchel and procreated thirteen children with her, of whom two acted as creator gods. The mother goddess, who has been identified in the codices as the Goddess $\mathrm{O}$, shares the oldness with Itzamnaaj. On page 74 of the Dresden Codex she helps him flood the world, in one of the deluges that ended one of the eras before our own. ${ }^{24}$ Thompson has picked up a current myth, which seems to have roots in ancient beliefs and that reports that the sun and moon were the first beings to have sexual intercourse, after a deer kick formed the female genitalia of the moon. ${ }^{16}$

But if the cosmos as a whole has its origin in a unique creator god, due to the scheme of thought that finds application in the Mayan worldview and then we must ask ourselves: Why do the Maya think of the original creator gods as a couple formed by a man and a woman? Itzamnaaj being assigned a wife alludes to sexual activity. In the Altiplano, the codices display several images showing a human couple, probably the couple formed by the creator gods, with intertwined legs, partially covered by a kind of blanket, which hint at the sexual act (Figure 18).${ }^{19}$ For the Maya, all creationist acts, such as the creation of

\footnotetext{
${ }^{19}$ Codex Vaticanus A; $; 8$ Borgia Codex $;{ }^{59}$ Codex Vaticanus B. ${ }^{60}$
}

the world, the fertility of the earth, the growing of plants and the fruit of corn, are manifestations of the primordial cosmic force, from which they have arisen and which they remain attached to. Similarly, the act of human reproduction participates from the life-generating power that has created everything. Therefore, the supreme deity, besides being responsible for the primordial creation, is also responsible for human procreation. But this does not yet explain why the origin is thought of as a divine couple.

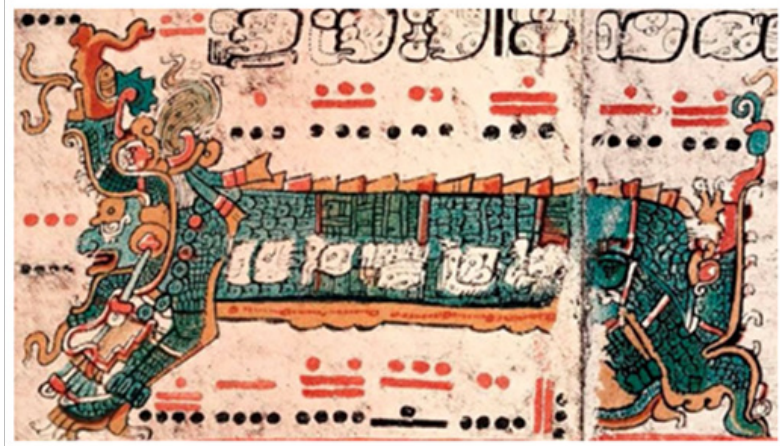

Figure 17 Itzamnaaj as terrestrial crocodile. Dresden Codex, page 4

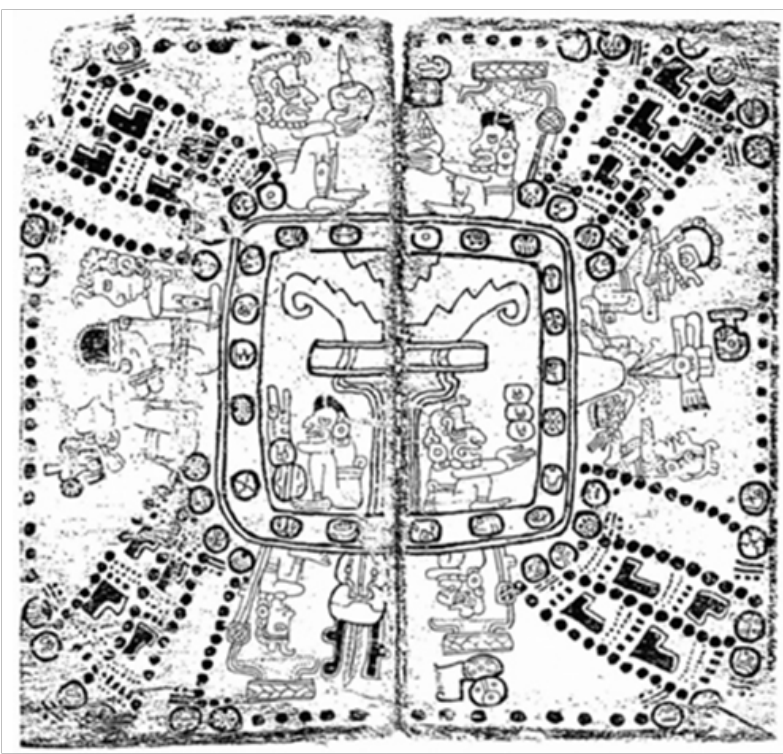

Figure 18 The creation couple. Madrid Codex, pages 75 and 76

The logic of action, besides being logic of origin, is also a logic of identity. The origin is thought (partially) identical to what comes from it. If the act of human procreation is seen as being linked to the primordial cosmic energy, which is credited with creation and procreation results from the sexual union between man and woman, then the origin must be thought of as a primordial couple formed by creator gods. For the origin, under this logic, is thought of as with the characteristics of the event that has emerged from it. The origin has a relationship of identity with what resulted there from, so the primordial origin, the cosmic fecundating principle, assumes the form of a couple. ${ }^{61}$

\section{Conclusion}

The existence of sacred forces in the Mayan cosmo-vision can be explained by the cognitive scheme through which they perceived and interpreted their world. This scheme is none other than that which builds every member of the human species in the early stages of his 
biography in order to interact with the person who assumes his care and then generalizes it in dealing with the environment that surrounds him. The inability of all human beings to ensure their survival at the moment of their birth promotes a process that stimulates the acquisition and increase of the competition of actions. Due to the lack of fixed structures that genetically determine their behavior, every human being is forced to construct the reality before him, in a spatially ordered, temporal and causal world. The fact that the construction of the world occurs simultaneously with the increase in the competition of actions has definite consequences. Because the human being at the early stage of ontogenesis experiences reality through their actions, reality is understood through a scheme that remains attached to action. Both cognitive structures and the development of the structure of action are parts of the same process. Thus, structures that experience their construction in action remain attached to this also in the cognitive system. When the scheme of action is applied to make the world understandable we speak of the logic of action.

This logic registers an investment in the direction that the action follows in its application in the understanding of the world. The scheme of the action parts from a beginning and is directed to a goal, which, once achieved, means the end of the action. In the interpretations in which this scheme finds application, the scheme starts from a fact or event that is before it, follows its development in an inverse direction and finds in the subject (and its substance) the explanatory moment of the origin. But, this is not enough to understand the interpretations of reality that make up a belief system, we must consider the active moment of the application of the cognitive scheme, which reflects the experiences that a culture makes with an already existing world. Therefore, the particularities of the Mayan deities result from the highly specific forms of application of the schemes and the interest of the Maya in certain aspects of reality.

Since the first object scheme that every human being constructs is the scheme of the subject, the application of this scheme in the perception and interpretation of the objects and phenomena of the world gives rise to a fantastic universe in which forces inside or behind them determine them. This way, in the view of the Mayan world, phenomena are understood as a result of the will of beings imagined according to the model of the subject: the movement of the sun is due to the permanent journey undertaken by K'inich Ajaw through the sky during the day and through the underworld at night, the rain falls when Chahk waters the world with a pitcher or when he urinates and everything that exists is due to the creator god Itzamnaaj.

The scheme of action as the functioning logic of thought also helps to explain the way in which the Maya established relations between some animals and the highest deities. As the representations from the Classic show, Itzamnaaj was identified with the Principal Bird Deity and with the celestial and terrestrial monster, an animal with crocodile features. Due to the scheme that the Mayans applied to understand the world, the qualities were understood as emanations of a subject and/or a substance that is behind them and which they remain attached to. Anywhere qualities appeared that were considered proper of a deity, its presence was perceived. Therefore, objects or animals that possessed such qualities were (partially) identical to it. This way, the link between divinity and the bird was established through a highly significant feature: The bird could transit, like the supreme deity, through the heavens. Something similar happened with the relationship between the crocodile or alligator and the supreme deity: The reptile was attributed the power to resurface to life, after losing it in the depths of the water. The images of Itzamnaaj as a bird or as a crocodile are not an expression of an inexplicable symbolism then, they are a manifestation of the structure that the Maya applied to make their reality understandable.

The Maya considered that the world had been created by a couple of gods. To explain this belief, it is necessary to keep in mind the scheme that governed their thinking. When it comes to explaining the world, the logic of action forces us to think about the origin, which keeps a relationship of identity with what emerges from it. This leads to think of the origin as a creative process that shows the traits that are characteristic of a creative process in the real world, such conceptualization is supported by a causality that attributes creation, fertility, fertilization, birth, maturation or germination to a single cause, which finally refers to the absolute cause. The explanation must then resort to the creative, productive or generative processes their experience is familiar with.

The Maya were satisfied with an explanation of the origin that only alluded to the sexual activity of the creator gods. Of course, they knew that the sexual union of the gods did not originate the world, but, for their thinking, the quality of the explanation did not depend on the exact physiological description of the act of generation. Their way of thinking only requires mentioning the thematic field that is relevant. Because, as mentioned every form of creation converges into a final cause that originates all forms of creation. To describe the beginning of creation, it is only necessary to identify the sexual activity from which the initial creation began. No matter how this act gave rise to the world, for a mind, such as the Maya, which maintains the object and the origin closely linked, the act of creation can be expressed very well in the activity or in the known natural processes that intervene in some form of fertilization.

In the scheme of thought, the beginning is always the subject, but that does not say much. It is necessary for what this subject performs to assume a substance that is also conceived as the beginning in the real world: to procreate or fertilize are the semantic fields the Maya resorted to, not because they had been more interested in natural phenomena than in religion, but simply because their thinking structure forced them to think of the origin of the world as an activity that is also creative in the real world.

\section{Acknowledgements}

None.

\section{Conflict of interest}

Author declares that there is no conflict of interest.

\section{References}

1. Barrios GA. Dioses del cielo, dioses de la tierra. Los mayas Voces de piedra, Ámbar Diseño. México; 2011. p. 181-194.

2. Nikolai G. Los libros de papel plegado. Los Mayas Voces de Piedra, México; 2011. p. 151-166.

3. Andreas TK. The Major gods of ancient Yucatan. Studies in PreColumbian Art \& Archaeology. 1992;32:1-160.

4. Francois BC. Una historia de la religión de los antiguos mayas. Centro de Estudios Mexicanos y Centroamericanos, México; 2004. p. 427.

5. Andrea S, Zender M. Maya Reading Art. A Hieroglyphic Guide to Ancient Maya Painting and Sculpture. In: Thames, Hudson, editors. UK; 2001. p. 248 
6. Luis BVJ. El culto al sol en las cuevas mayas. Memoria de la II Mesa Redonda de la Sociedad Española de Estudios Mayas, Spain; 1987. p. $123-131$.

7. Eugenia GGM. La personificación del tiempo entre los mayas. Estudios de Cultura Maya. 2004;25:17-32.

8. Miguel RD. La Tríada de Palenque: Una historia sagrada de los mayas antiguos. In: Santiago M, editor. Los rostros de Dios, Instituto Universitario de Ciencias de las Religiones, Spain; 2011. p. 237-269.

9. Mercedes G. Las fuerzas sagradas del universo maya. Periodo Postclásico. In: Eduardo MM, editor. Los últimos reinos mayas, Lunwerg Editores, Spain; 1998. p. 99-130.

10. Elena SSL. Los Códices Mayas Prehispánicos en la Era Digital. Revista Digital Universitaria. 2012;13(12).

11. Elena SSL. Los dioses: energía en el espacio y en el tiempo. In: Garza, et al. editor. Religión maya. Ediciones Trotta, Madrid, Spain; 2002.

12. Simon M. The Old Man of the Maya Universe: A Unitary Dimension to Ancient Maya Religion. Maya Archaeology. 2015;3:186-227.

13. Paul S. Die Göttergestalten der Mayahandschriften, Verlag von Julius Springer: Germany; 1903.

14. Diego LC. Historia del Yucatán. Editorial Linkgua, Spain; 2007. p. 504.

15. Tomás PS. Dioses mayas. Arqueología mexicana. 2007;15(88):57-65.

16. Eric T. Historia y religión de los mayas. Editorial Siglo 21, México; 2014. p. 485.

17. Andreas KT. Antiguos dioses mayas. Arqueología Mexicana.1996;4(20):20-36

18. Rogelio VR. Las múltiples caras de la divinidad, Complejos de dioses en la religión maya. In: Alejandro S, editor. Religión Maya: rasgos y desarrollo histórico, Universidad de Ciencias y Artes de Chiapas UNICACH, México; 2013. p. 223-236.

19. Miguel RD. La religión maya. Alianza Editorial, Spain; 1986.

20. Linda S, Ellen MM. The Blood of Kings: Dynasty and Ritual in Maya Art. Archeology. 1986;39(3):60-63.

21. Stephen HD, Stuart D. On gods, glyphs and kings: divinity and rulership among the Classic Maya. Antiquity. 1996;(70):289-312.

22. Francois CB. Los dioses mayas. Una aparición tardía. Arqueología mexicana. 2007;15(88):32-41.

23. Nikolai G, Simon M. Crónica de los reyes y reinas mayas: La primera historia de las dinastías mayas. Editorial Crítica, Spain; 2002. p. 240.

24. Günter D. Die Zeit in der Geschichte: Ihre Entwicklungslogik vom Mythos zur Weltzeit. Suhrkamp, Germany; 1989. p. 477.

25. Hallpike CR. The foundations of primitive thought. Los fundamentos del pensamiento primitivo, Clarendon Press, Oxford University Press, USA 1979.

26. Ulrich W. Dynamismus und Finalismus ZurStrukturlogik der aristotelichen Naturphilosophie. In: Dux G, Wenzel U, editors. Der Prozess der Geistesgeschichte: Studien zur ontogenetischen und historischen Entwicklung des Geistes, Suhrkamp, Germany; 1994. p. 336-374.

27. Laura IG. Creencias, mitos y rituales en el mundo prehispánico. Universidad de Guadalajara, México; 2007.

28. Günter D. Die Logik der Weltbilder: Sinnstrukturen im Wandel der Geschichte, Suhrkamp, Germany; 1982.

29. Laura IG. Los sacrificios humanos. Una explicación desde la teoría histórico-genética. Estudios de Cultura Náhuatl. 2001;32:341-358.
30. Mercedes DG. Las fuerzas sagradas del universo maya, Los mayas del periodo Clásico. In: Moctezuma M, editor. Los últimos reinos mayas, Spain; 1997. p. 101-140.

31. Martha CG. Los incensarios del Grupo de las Cruces, Palenque Arqueología Mexicana. 2000;8(15):54-62.

32. David S. The Inscriptions from Temple XIX at Palenque. The PreColumbian Art Research Institute, San Francisco. USA; 2005.

33. Mercedes G. El tiempo del mito. Artes de México, Mexico; 2012. p. $36-44$.

34. Dresde C. Interpretación de Erik Velázquez García. Arqueología Mexicana Parte 2, Mexico; 2017.

35. David S. Las inscripciones del Templo XIX de Palenque. The PreColumbian Art Research Institute, Estados Unidos, USA; 2010.

36. Montejo V. Popol Vuh: Libro Sagrado de los mayas. Artes de México, México; 2010. p. 96.

37. Antonio CR. Calepino Maya De Motul. In: Plaza, Valdés, editors México; 2001.

38. Griswold MS. La Civilización maya. Fondo de Cultura Económica Mexico; 1994

39. Gabrielle Vail. Códice de Madrid. Universidad Mesoamericana, Spain 2013.

40. Michael DC. The Hero Twins: Myth and Image. In: Justin K, editor. The Maya Vase Book (Vol I), Kerr Associates, US; 1989. p. 161-184.

41. Dresde C. Interpretación de Erik Velásquez García. Arqueología Mexicana Parte 1 Edición Especial 67, Mexico; 2016.

42. Bernardo LF. Historia de Yucatán y Devocionario de Nuestra señora de Izmal y Conquista espiritual. Imprenta del Museo Nacional de México, México; 1893.

43. Mercedes G. Relaciones histórico-geográficas de la gobernación de Yucatán (Mérida, Valladolid y Tabasco). Universidad Nacional Autónoma de México, México; 1983.

44. Alfredo BV. Diccionario Maya Cordemex: maya-Español. Españo Maya. Ediciones Cordemex, México; 1980.

45. Francis R, Donald HM. The Maya Book of the Dead: The Ceramic Codex. University of Virginia Art Museum, USA; 1981.

46. Barrios AB. El mito del diluvio en las ceremonias de entronización de los gobernantes mayas. Agentes responsables de la decapitación del saurio y nuevas fundaciones. Estudios de Cultura Maya. 2015;45:9-48.

47. Diego L. Relación de las Cosas de Yucatán. Ediciones Promo Libro, Spain; 2003.

48. Erik VC. Una nueva interpretación del Monstruo Cósmico Maya. Arte y Ciencia. XXIV Coloquio Internacional de Historia del Arte, México; 2002. p. 419-458.

49. Andreas TK. Una representación de la deidad ave principal en el Códice de París. Research Reports on Anciant Maya Writing 6. Center for Maya Research, USA; 2009.

50. Constance C. The Principal Bird Deity in Preclassic and Early Classic Maya Art. Master's Thesis, Texas University, USA; 1986.

51. Mercedes GC. Aves sagradas de los mayas. Editorial Universidad Nacional Autónoma de México, México; 1995.

52. David F, Linda S, Joy P. Maya Cosmos: Three thousand Years on the Shaman's Path. In: Collins H, editor. William Morrow and Company, USA; 1993. p. 543

53. Linda S, Peter M, Everton M. The Code of Kings: The Language of Seven Sacred Maya Temples and Tombs. Touchstone editors, USA; 1999. 
54. Erik VC. El mito maya del diluvio y la decapitación del caimán cósmico: The Maya Floof Myth and the Decapitation of the Cosmic Caiman. PARI Journal. 2006;7(1):1-10.

55. Ernesto V, Teri AO. El cocodrilo y el cosmos: Itzamkanac, el lugar de la casa del lagarto. In: Laporte JP, editor. XVIII Simposio de investigaciones arqueológicas, Museo Nacional de Arqueología y Etnología, USA; 2004 p. 14-26.

56. Andreas TK. Itzam Cab Ain: Caimanes, cosmología y calendario en el Yucatán del período Postclásico. Research Reports on Ancient Maya Writing (26). Center for Maya research, USA; 2009.

57. Antonio MB. Los libros de Chilam Balam de Chumayel. Fundación Editorial el perro y la rana, Venezuela; 2008. p. 9-115.
58. Vaticanus CA. Graz: Akademische Druck-und Verlagsanstalt. Col Códices Selecti. 1979;65.

59. Borgia B. Graz: Akademische Druck-und Verlagsanstalt. Col Códices Selecti. 1976;58.

60. Vaticanus CB. Graz: Akademische Druck-und Verlagsanstalt Col Códices Selecti $1972 ; 36$.

61. Laura IG. El origen de algunos dioses prehispánicos. Una explicación desde la teoría histórico-genética. Estudios de Cultura Náhuatl. $2005 ; 36: 273-300$. 